\title{
A role for multiple chimeric antigen receptor-expressing leukocytes in antigen-specific responses to cancer
}

\author{
Carmen S.M. Yong ${ }^{1}$, Liza B. John ${ }^{1}$, Christel Devaud ${ }^{1,2}$, Miles H. Prince ${ }^{1}$, Ricky W. \\ Johnstone ${ }^{1}$, Joseph A. Trapani ${ }^{1}$, Phillip K. Darcy ${ }^{1,3, *}$, Michael H. Kershaw ${ }^{1,3, *}$ \\ ${ }^{1}$ Sir Peter MacCallum Department of Oncology, University of Melbourne, Parkville, Victoria, Australia \\ ${ }^{2}$ Institut de Recherche en Santé Digestive, Université de Toulouse, INPT, INRA, INSERM UMR1220, UPS, France \\ ${ }^{3}$ Department of Immunology, Monash University, Prahran Victoria, Australia \\ *These authors contributed equally to this work
}

Correspondence to: Phillip K Darcy, email: phil.darcy@petermac.org Michael H Kershaw, email: michael.kershaw@petermac.org

Keywords: T cells, macrophages, NK cells, chimeric antigen receptor, transgenic mouse

Received: March 16, 2016

Accepted: April 16, 2016

Published: May 03, 2016

\section{ABSTRACT}

While adoptive immunotherapy using chimeric antigen receptor (CAR)-modified $T$ cells can induce remission of some tumors, the role of other CAR-modified leukocytes is not well characterized. In this study, we characterize the function of leukocytes including natural killer (NK) cells, macrophages and CAR T cells from transgenic mice expressing a CAR under the control of the pan-hematopoietic promoter, vav, and determine the ability of these mice to respond to ERB expressing tumors. We demonstrate the anti-tumor functions of leukocytes, including antigen specific cytotoxicity and cytokine secretion. The adoptive transfer of CAR T cells provided a greater survival advantage in the E0771ERB tumor model than their wildtype (WT) counterparts. In addition, CAR NK cells and CAR T cells also mediated increased survival in the RMAERB tumor model. When challenged with Her2 expressing tumors, F38 mice were shown to mount an effective immune response, resulting in tumor rejection and long-term survival. This was shown to be predominantly dependent on both $\mathrm{CDB}^{+} \mathrm{T}$ cells and NK cells. However, macrophages and $\mathrm{CD4}^{+} \mathrm{T}$ cells were also shown to contribute to this response. Overall, this study highlights the use of the vav-CAR mouse model as a unique tool to determine the anti-tumor function of various immune subsets, either alone or when acting alongside CAR T cells in adoptive immunotherapy.

\section{INTRODUCTION}

Adoptive immunotherapy has demonstrated great clinical success as a form of treatment for cancer. In particular, the adoptive transfer of cytotoxic lymphocytes (CTLs) genetically modified to express a chimeric antigen receptor (CAR) specific for a tumor associated antigen (TAA) has shown great promise, with the most recent clinical success in blood cancers such as Chronic Lymphocytic Leukemia (CLL) and Acute Lymphoblastic Leukemia (ALL) [1-5]. However, the use of adoptively transferred CAR T cells into solid cancers has been met with numerous hurdles, and subsequently has struggled to gain similar success $[6,7]$. In leukemic or lymphoma models of disease, adoptive transfer of genetically modified $\mathrm{T}$ cells come into contact with the tumor cells almost immediately, reducing the need to localize and persist at the tumor site. In contrast, solid tumors present numerous challenges; with issues arising involving the persistence and survival of transferred T cells, the inability of $\mathrm{T}$ cells to penetrate the tumor mass and maintaining their effector cell function within an immunosuppressive tumor microenvironment [8-10]. The ability of CAR $\mathrm{T}$ cells to overcome these multiple factors alone has proven to be inadequate. However, these issues may be resolved by using alternate types of CAR-expressing leukocytes, either alone or in combination.

Evidence suggests that concurrent transfer of other immune subsets may overcome some of the issues in tackling solid tumors using adoptive immunotherapy, 
either through directly increasing the effector function of CTLs or by modification of the surrounding tumor microenvironment into an anti-tumoral environment. Multiple studies have demonstrated an enhanced anti-tumor effect when both $\mathrm{CD}^{+}$and $\mathrm{CD} 8^{+} \mathrm{T}$ cells were adoptively transferred, compared to $\mathrm{CD}^{+} \mathrm{T}$ cells alone [11-14]. Furthermore, the adoptive transfer of irradiated macrophages has been shown to aid in the localization and activity of adoptively transferred $\mathrm{T}$ cells through repolarisation of the tumor microenvironment, facilitating a more receptive environment for $\mathrm{T}$ cell function [15]. While a handful of studies have hinted at the potential of CAR modified monocytes, very few studies have attempted to fully understand or demonstrate their ability to function via a CAR $[16,17]$. Furthermore, whilst CAR expressing $\mathrm{CD}^{+} \mathrm{T}$ cells, and to a much lesser extent NK cells, have been studied in detail, there has been little work into the role and function of other immune subsets expressing a CAR [18-25].

In order to study the role of various immune subsets when genetically modified with a CAR, we generated a transgenic mouse model in which all immune cells express the same chimeric antigen receptor recognizing the same tumor antigen. To ensure the expression of the CAR was limited specifically to immune cells, we utilized the vav promoter, a protein whose expression is restricted to cells of the hematopoietic lineage, to drive the expression of the chimeric antigen receptor. Previous transgenic models utilizing the vav promoter have demonstrated its capability in driving transgene expression in all immune subsets regardless of lineage or maturation state [26-28]. The chimeric antigen receptor used in our studies is comprised of $\mathrm{T}$ cell intracellular signaling domains, derived from $\mathrm{CD} 3 \zeta$ and $\mathrm{CD} 28$, linked to an extracellular single chain variable fragment specific for the tumor antigen, ErbB2 (Her2). Using this novel mouse model, we recently validated the ability of the vav promoter to drive the expression of a chimeric antigen receptor throughout multiple immune subsets [29]. We generated two different strains of the vav-CAR mice, each with varying immune compositions and levels of receptor expression. F9 mice harboured almost 270 copies of the transgene, had high levels of receptor expression however were distinctly reduced in the number of $\mathrm{B}$ and $\mathrm{T}$ lymphocytes present in the thymus, lymph nodes and spleen. F38 mice were normal in immune composition but had a lower level of receptor expression, with only 7 copies of the $v a v$-CAR transgene present in these mice.

In the present study, we report that the presence of the CAR enables recognition and subsequent multifaceted effector functions in both NK and T cells, and also suggests an important antigen-specific role for macrophages and $\mathrm{CD}^{+} \mathrm{T}$ cells in tumor rejection. This mouse model may provide a deeper understanding of the capabilities of other CAR bearing immune subsets in the context of adoptive immunotherapy.

\section{RESULTS}

We have previously shown the vav promoter was proficient in driving the expression of the CAR against the human Her2 antigen in a range of hematopoietic cells, of both myeloid and lymphoid origin in two transgenic mouse models [29]. Immune characterization and phenotypic studies of F9 mice revealed that the high copy number of transgenes present had altered the T cell development of these mice, resulting in an abnormal immune composition with a severe reduction in the proportion of lymphocytes. The immune composition of F38 mice was comparable to WT mice, with high levels of CAR expression observed on all immune subsets with the exception of B cells. Having established the expression of the receptor on multiple immune subsets, we next explored the functional relevance of the CAR in these immune cells.

\section{Transgenic CAR T cells display antigen specific function}

The majority of adoptive transfer studies have utilized $\mathrm{CD}^{+} \mathrm{T}$ lymphocytes, exploiting their ability to secrete high levels of cytokine and mediate immediate cytolytic killing upon antigen recognition. We had previously validated the level of CAR expression on resting $\mathrm{CD}^{+} \mathrm{T}$ lymphocytes, however it was not clear whether CAR expression differed post activation. As adoptive transfer experiments often require long periods of in vitro expansion, stable CAR expression during activation and proliferation remains an integral factor for these studies. We observed similar proportions of $\mathrm{CD}^{+}$ and $\mathrm{CD}^{+} \mathrm{T}$ cells from 5-day in vitro cultured (activated) $v a v-\mathrm{CAR}$ and WT mice splenocytes activated with a combination of anti-CD3/28 and recombinant cytokines (Figure 1A). However, while the proportion and level of CAR expression (as measured by mean fluorescence intensity (MFI)) on $\mathrm{CD}^{+} \mathrm{T}$ lymphocytes remained stable over the 5 day culture, we observed a decrease in both proportion and level of CAR expression on $\mathrm{CD}^{+} \mathrm{T}$ lymphocytes stimulated the same way (Figure 1B-1C).

Having demonstrated expression of the CAR on these T cells, we then further characterized whether the CAR was functional. The ability of $\mathrm{T}$ lymphocytes to recognize and respond to antigen in vitro has commonly been assessed through measuring the release of cytokine. In vitro activated $\mathrm{T}$ lymphocytes were co-cultured overnight with a specific agonistic antibody for the CAR ( $\alpha$-c-myc tag), or with the fibrosarcoma cell line 24JK expressing the ERB antigen (24JKERB). Stimulation through the isotype antibody (IgG2a) or antigen negative targets (24JK) induced neglible levels of cytokine from CAR $T$ cells. However, following stimulation with $\alpha$-c-myc tag monoclonal antibody or the tumor cells 24JKERB, we detected a range of cytokines, including IL-4, IL-2, IL-17A, TNF- $\alpha$, IL-6 and IFN- $\gamma$ from CAR T 
cells, while no significant response was observed from WT T cells (Figure 2A-2F).

In addition to cytokine production, cytotoxicity is another measure of $\mathrm{T}$ cell function. Moreover, the ability to unleash immediate cytotoxic function upon recognition of a target antigen is one of the pivotal characteristics that has driven the success of CAR T cells in adoptive immunotherapy. We sought to assess the ability of CAR T cells to kill in an antigen specific manner in a chromium release assay. WT T cells showed similarly low levels of killing from both the parental and ERB expressing targets (Figure 2G). Both F9 and F38 T cells were capable of mediating antigen specific cytotoxicity against the tumor line 24JKERB while minimal killing was observed against the antigen negative control 24JK (Figure 2H-2I). This result was even observed at a 1:1 ratio for $\mathrm{F} 38 \mathrm{~T}$ cells, indicating CAR T cells are capable of mediating a high level of antigen specific cytotoxicity at reduced effector:target ratios

\section{In vitro cytokine and cytotoxicity from CAR NK cells}

The use of CAR-bearing NK cells has also shown great promise as a form of therapy, however due to the difficulty in generating sufficient numbers of genemodified primary murine NK cells, a majority of studies have utilized NK cell lines or human NKs [25, 30-32]. Therefore, the use of primary mouse NK cells and their function when genetically modified with a CAR has not been extensively studied. We had previously established the ability of primary mouse NK cells electroporated to express a CAR, however expression of the CAR was transient in these cells due to the method of genetic modification [22]. One caveat of utilising NK cells for adoptive immunotherapy is the need to overcome inhibitory signals, which may dampen the immune response. It is well established that the killing capability of NK cells relies on a fine balance between the level of
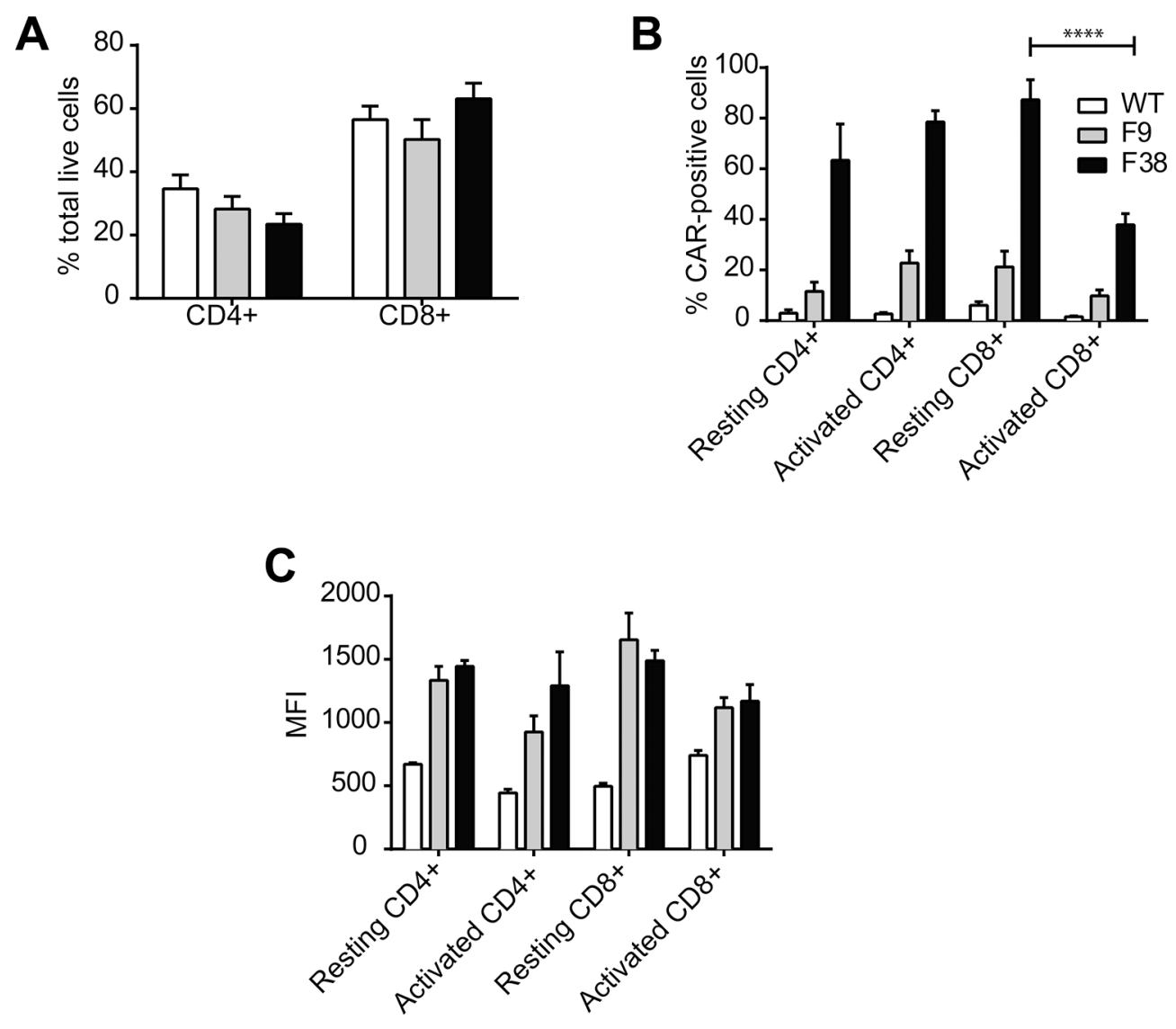

Figure 1: CAR expression in naïve and activated T cells. Splenocytes from WT, F9 and F38 mice were harvested and activated overnight with $\alpha-\mathrm{CD} 3 \varepsilon$ and $\alpha-\mathrm{CD} 28$ in the presence of rhIL-2 and mIL-7 and cultured in vitro for 5 days. Activated T cells were then stained for FACS with the following markers; CD3, TCRb, CD4, CD8, $\alpha$-c-myc tag-A488 and IgG2a-A488. (A) The proportion of CD4 ${ }^{+}$and CD $8^{+}$ $\mathrm{T}$ cells, $(\mathbf{B}) \mathrm{CAR}^{+} \mathrm{T}$ lymphocytes and $(\mathbf{C})$ the mean fluorescence intensity (MFI) of CAR expression on gated lymphocytes was analysed. The MFI of cells from wild type mice represents the negative control level of fluorescence. Data represents mean \pm standard error of the mean (SEM) of 4 (resting) or 10 (activated) independent experiments $* * * * p<0.0001$. 
A

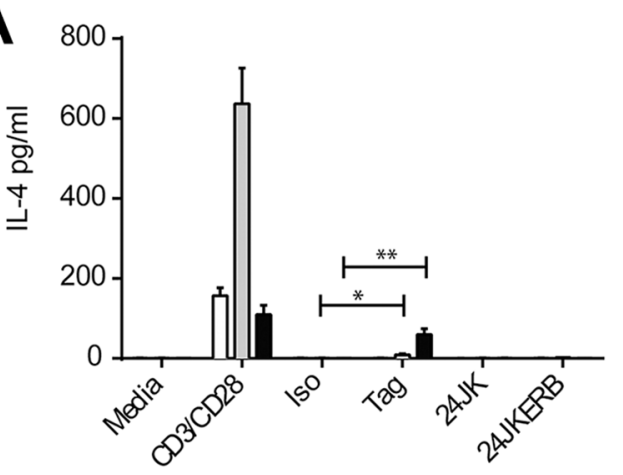

C

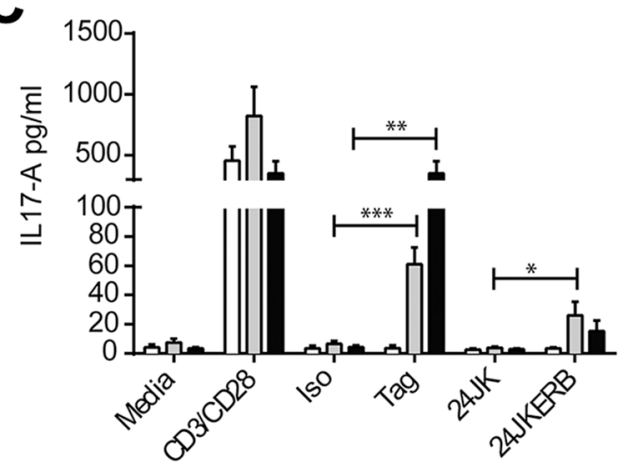

E

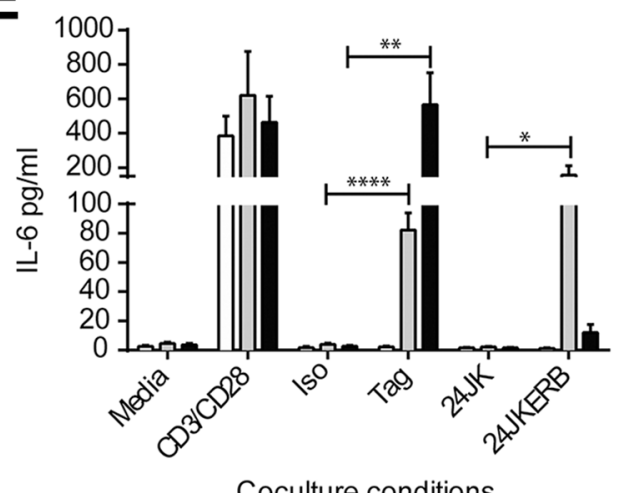

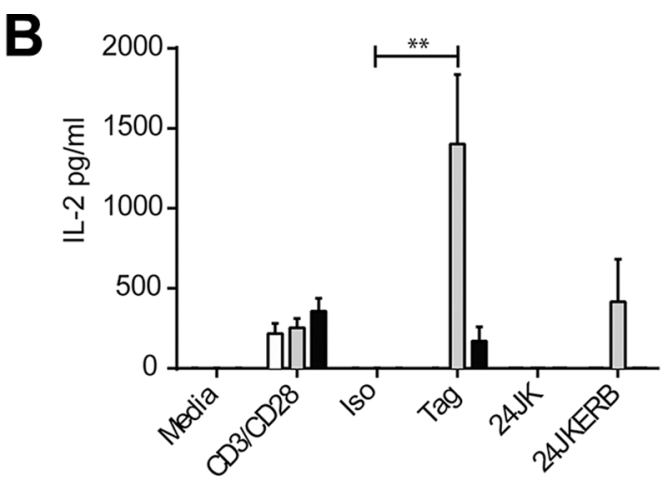

D

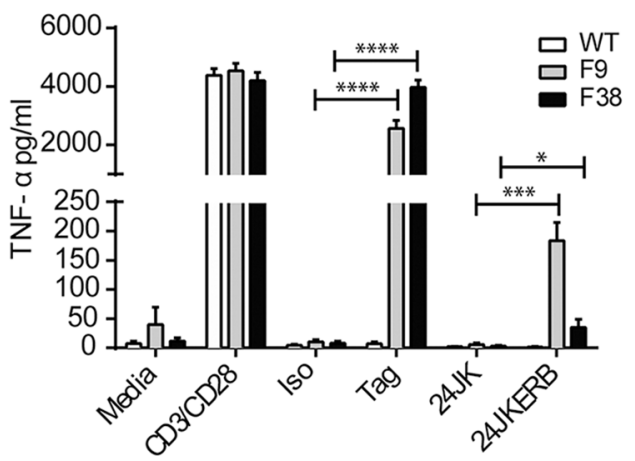

$\mathbf{F}$

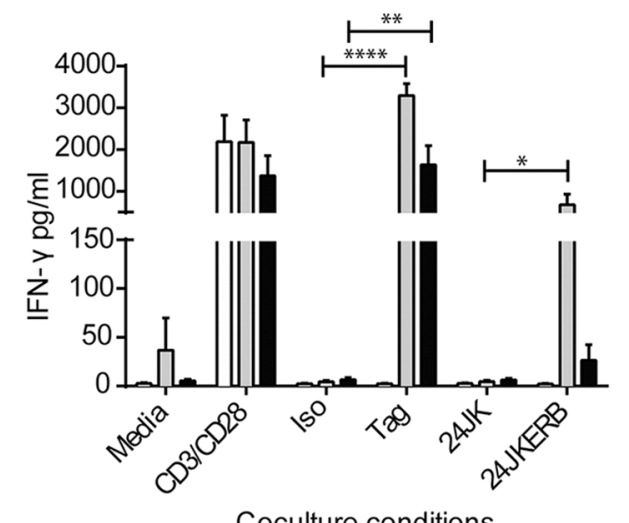

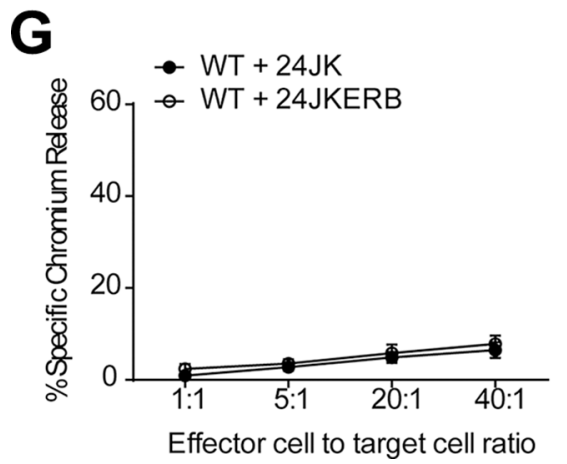
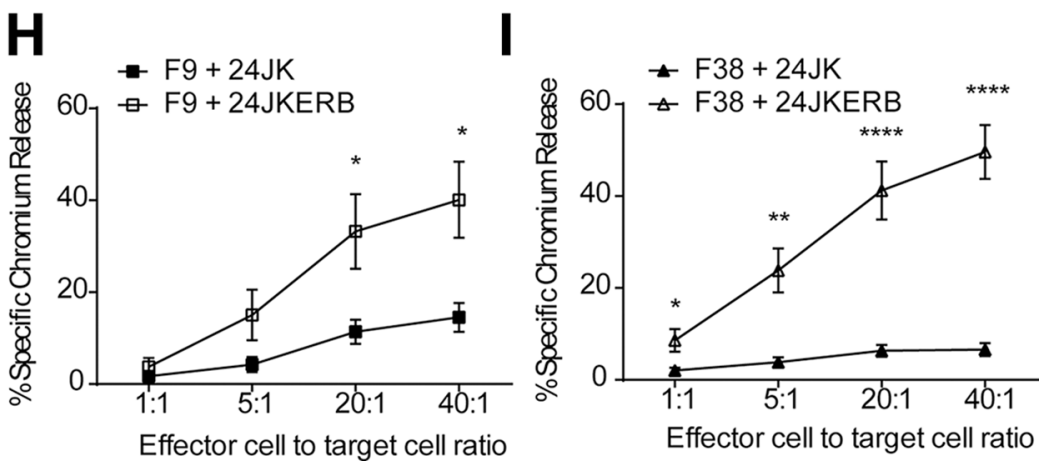

Figure 2: Antigen specific function from CAR T cells. (A-F) In vitro activated T cells were co-cultured overnight in the presence of media, immobilized anti-CD3 $\varepsilon$ and anti-CD28, agonistic c-myc tag or isotype IgG2a and tumor targets 24JK and 24JKERB. Supernatant was harvested the next day and analysed for cytokine secretion using cytometric bead array. Data represents mean \pm SEM for 4 independent experiments (total of 7-8 mice/strain). (G-I) In vitro activated T cells were co-cultured with ${ }^{51} \mathrm{Cr}$ labeled tumor targets 24JK or 24JKERB in a 4-hour killing assay at various effector to target ratios. The level of antigen-specific killing was assessed by the amount of free chromium released into the supernatant after 4 hours. Data represents mean \pm SEM for 6 independent experiments (total of $7-8$ mice/strain). ${ }^{*} p<0.03$, ${ }^{* *} p<0.009,{ }^{* * *} p<0.0004,{ }^{* * * *} p<0.0001$. 
activating and inhibitory signals received. Interaction of the major histocompatibility complex class I (MHC Class I) molecule results in triggering of intracellular inhibitory signaling pathways in NK cells and subsequently terminates any effector function [33]. To determine whether the CAR could override the inhibitory signals and induce antigen specific cytokine secretion or cytotoxicity, we added in our experiments the murine lymphoma cell line RMA, which express high levels of MHC Class I.

Given the relatively high level of expression of CAR on NK cells from F38 mice described previously [29], we focused on cells from this mouse strain for our NK cell studies. We detected low levels of multiple cytokines from in vitro activated F38 CAR NK cells in response to both 24JKERB and RMAERB target cells, with negligible levels produced against the parental targets $(24 \mathrm{JK}$ and RMA) or from WT NKs against all targets (Figure 3A-3C). CAR NK cells were observed to secrete a higher level of IL-17A following stimulation with $\alpha$-c-myc tag antibody, although there was no significant difference when cultured with the antigen expressing tumor targets (Figure 3A). TNF- $\alpha$ secretion was highest when CAR NK cells were co-cultured with either the $\alpha$-c-myc tag antibody or the RMAERB cell line (Figure 3B), where stimulation with the isotype control antibody (IgG2a) or the parental cell line RMA induced similar levels to WT NK cells. Parallel observations were observed with IFN- $\gamma$, with higher levels found in $\alpha$-c-myc tag stimulated or RMAERB co-cultures (Figure 3C).

We then assessed the cytotoxicity of CAR NK cells in a chromium release assay. Despite similar methods of isolation and activation, we observed an overall higher level of background killing from CAR NK cells against RMA targets compared to WT NKs (Figure 3D). However, while similar levels of cytotoxicity were observed from both WT and CAR NK cells against the parental RMA cell line (Figure 3D, NS at all E:T ratios), a comparison of WT and CAR NK cells co-cultured against RMAERB targets showed highly significant antigen specific cytotoxicity, indicating the ability of CAR NK cells to recognise and perform cytotoxic function through the chimeric antigen receptor (Figure 3D).

Since macrophages can also interact directly with microorganisms and diseased cells, we also investigated the antigen specific function of CAR-expressing macrophages in vitro. Given our previous findings, we chose to utilise F9 mice in this experiment due to the higher level of CAR expression in macrophages of this strain. Peritoneal exudate cells (PECs) were isolated from naïve WT or F9 mice and assessed for antigenspecific secretion of TNF- $\alpha$ and IL-6 (Figure 4A-4B). We observed higher levels of both cytokines from F9 PECs co-cultured against the $\alpha$-c-myc tag antibody, with little or no secretion was observed from the $\mathrm{IgG} 2 \mathrm{a}$ control or WT PECS. We next assessed if the phagocytic ability of macrophages would be altered by their expression of a CAR. Thioglycollate activated PECs were co-cultured with CFSE-labelled tumor targets and analysed by flow cytometry for the proportion of $\mathrm{CFSE}^{+}$macrophages. A significantly higher proportion of $\mathrm{CFSE}^{+}$macrophages were present in CAR macrophages cultured with RMAERB compared to culture with RMA (Figure 4C). Although further assessment is necessary before we are able to determine any anti-tumor potential of CAR macrophages, these experiments confirmed that the CAR on this cells is functional and can signal for both phagocytic uptake and cytokine secretion.

\section{Adoptive transfer of CAR T cells or CAR NK cells enhances survival of tumor bearing mice}

The vav-CAR mouse was generated as a tool to enable simple and easy isolation of CAR expressing immune subsets without the need for ex vivo genetic manipulation. Given the low numbers of $\mathrm{T}$ cells present in the F9 strain, we used T cells and NK cells isolated from F38 mice for adoptive transfer experiments. We first assessed the ability of CAR T and CAR NK cells to perform anti-tumor effector responses in vivo and whether the effector functions observed in vitro would translate in the Her2 mouse model. We found that the adoptive transfer of CAR T cells into E0771ERB subcutaneously tumor-bearing mice significantly inhibited tumor growth compared to mice treated with WT T cells (Figure 5A), and subsequently provided a significant survival advantage (Figure $5 \mathrm{~B}$ ). In a different tumor model, the adoptive transfer of CAR T cells or CAR NK cells into RMAERB tumor bearing mice also significantly increased survival (Figure 5C). This further validated the in vitro data and demonstrated that CAR T and CAR NK cells were capable of mediating anti-tumor effects in vivo. Future studies incorporating the combination of these two subsets would be important in order to elucidate potential synergistic effects.

\section{NK cells and $T$ cells are required for tumor rejection in vav-CAR mice}

In order to expand sufficient cells for therapeutic use, we utilized in vitro activated T cells and NK cells in our previous experiments. Whilst we demonstrated that the CAR remained detectable (data not shown) and functional post activation, considerable non-specific cytotoxicity was observed from both WT and CAR NK cells, possibly due to the methods of in vitro activation used. Therefore, we next determined whether we could achieve in vivo efficacy using naïve effector cells, and furthermore, if the presence of the CAR on multiple immune subsets would enable them to coordinate and mount an effective immune response in vivo against a tumor expressing the ERB antigen.

Naïve WT or vav-CAR mice were inoculated in the peritoneum with RMA or RMAERB cells and monitored for survival (Figure 6). CAR expression seemed to have no 

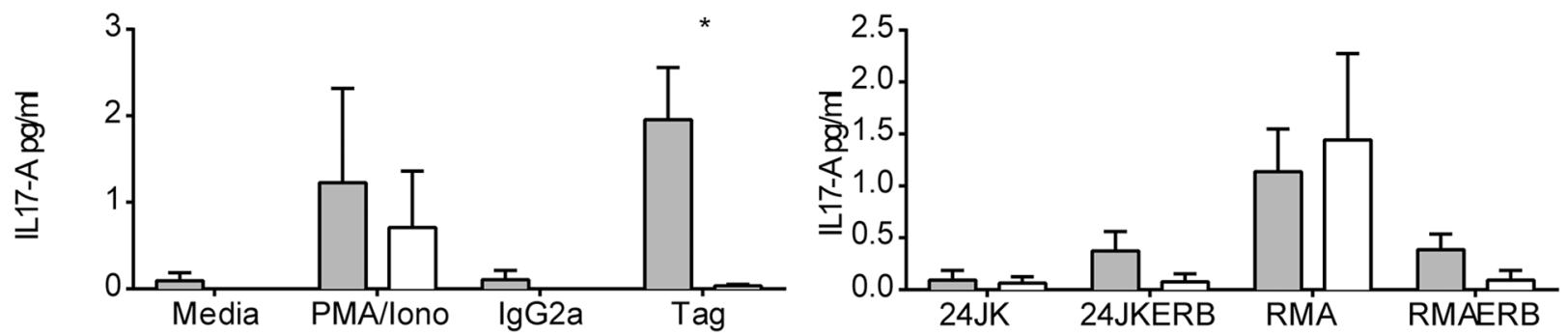

B
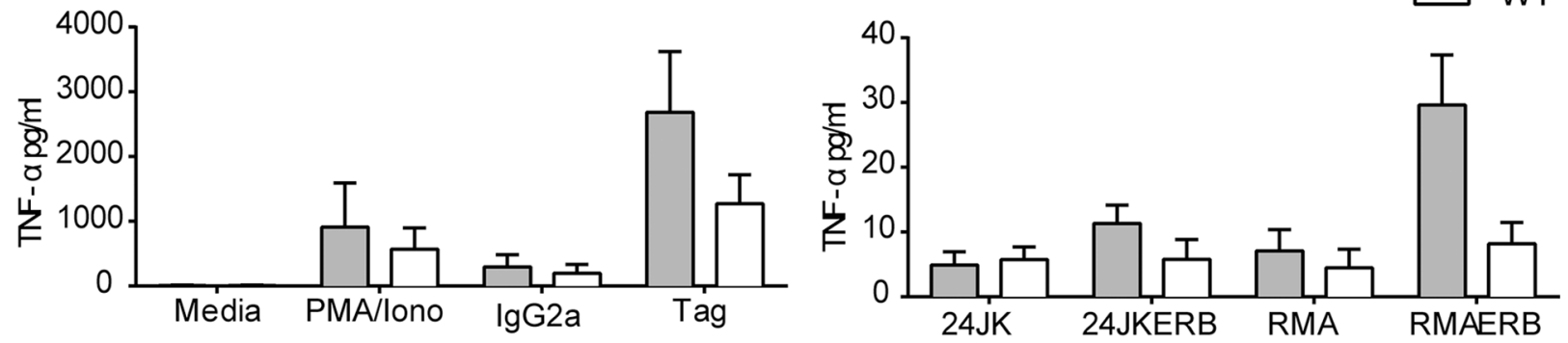

C
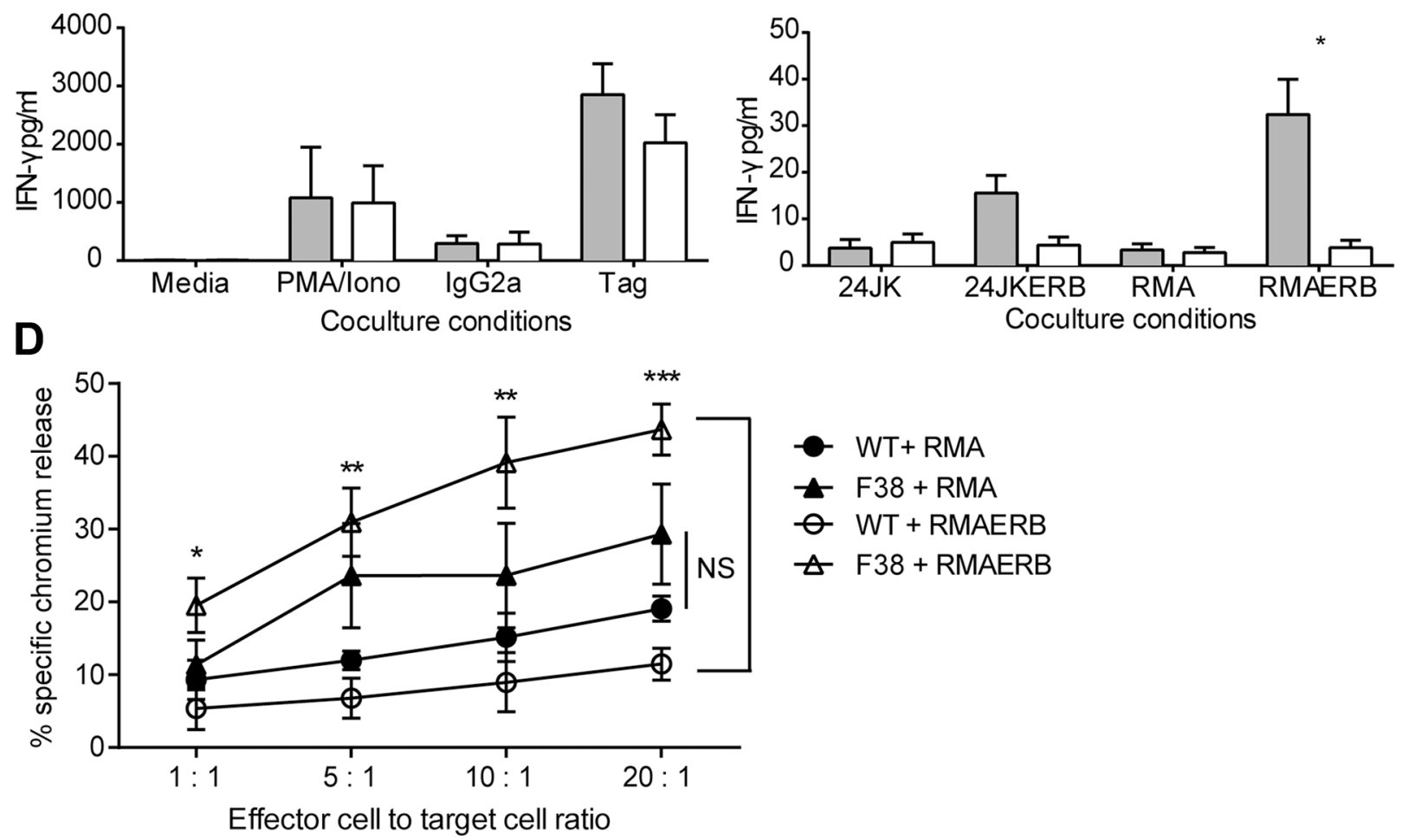

Figure 3: Natural killer cells expressing a CAR can mediate antigen-specific responses. (A-C) In vitro activated WT and CAR NK cells were co-cultured overnight in the following conditions; media, PMA/ionomycin, immobilized IgG2a or $\alpha$-c-myc tag or tumor targets 24JK/24JKERB and RMA/RMAERB at a 1:1 ratio. Supernatant was harvested the following day and assessed for cytokine secretion by CBA. Data represents mean \pm SEM for 3 independent experiments (total of 3 mice/strain) ${ }^{*} p<0.03$. (D) In vitro activated WT and CAR NKs were co-cultured with chromium labeled tumor targets RMA/RMAERB at various effector to target ratios and incubated for four hours. The supernatant was then harvested and assessed for the level of free chromium. The percentage of antigen specific cytotoxicity was then determined. Data represents mean \pm SEM for 4 independent experiments (total of 4 mice/strain). ${ }^{*} p<0.02,{ }^{* *} p<0.007,{ }^{* * *} p=0.0002$. 
effect on mice challenged with the RMA cell line, as both WT and vav-CAR mice all succumbed to tumor burden and were sacrificed at a similar timepoint. A significant proportion of F38 mice challenged with RMAERB were able to reject the tumor challenge, resulting in long term survival. In comparison, both WT and F9 mice showed similarly poor survival rates when challenged with RMAERB tumors.

To delineate the contribution of each immune subset in this tumor model, we depleted specific immune subsets in vivo (with weekly maintenance depletions) prior to RMAERB tumor inoculation. In WT mice, although the depletion of NK cells alone seemed to have no effect on survival, we observed a slight but significant decrease in survival following depletion of macrophages, $\mathrm{CD}^{+}$and $\mathrm{CD}^{+} \mathrm{T}$ cells as well as the combination of both NK cells and $\mathrm{CD}^{+} \mathrm{T}$ cells. However, the magnitude of the impact on survival was small. This suggested that endogenous (non-CAR related) immunity could have a minor role in tumor inhibition (Figure 7A). In F9 mice, the depletion of NK cells, macrophages and $\mathrm{CD}^{+} \mathrm{T}$ cells was found to reduce the survival advantage compared to irrelevant antibody control (IgG2a) treated mice (Figure 7B), however the median survival time of F9 immunodepleted mice compared to IgG2a-treated was similar. As these mice naturally have significantly lower numbers of $\mathrm{T}$ cells, this was result was not surprising. In contrast, in F38 mice, we observed a significant reduction in the survival advantage following immunodepletion with all treatments (Figure 7C). The anti-tumoral contribution of T lymphocytes and NK cells in F38 mice was apparent, with depletions of either subset completely ablating the survival advantage (Figure $7 \mathrm{C}$ ). The depletion of $\mathrm{CD}^{+} \mathrm{T}$ cells seemed to also have a profound effect on survival, reducing the median survival to 31 days. Interestingly, we also observed a decrease in the survival of mice treated with clodrolip (clodronate-liposomes), indicating that CAR expressing macrophages may indeed play a role in
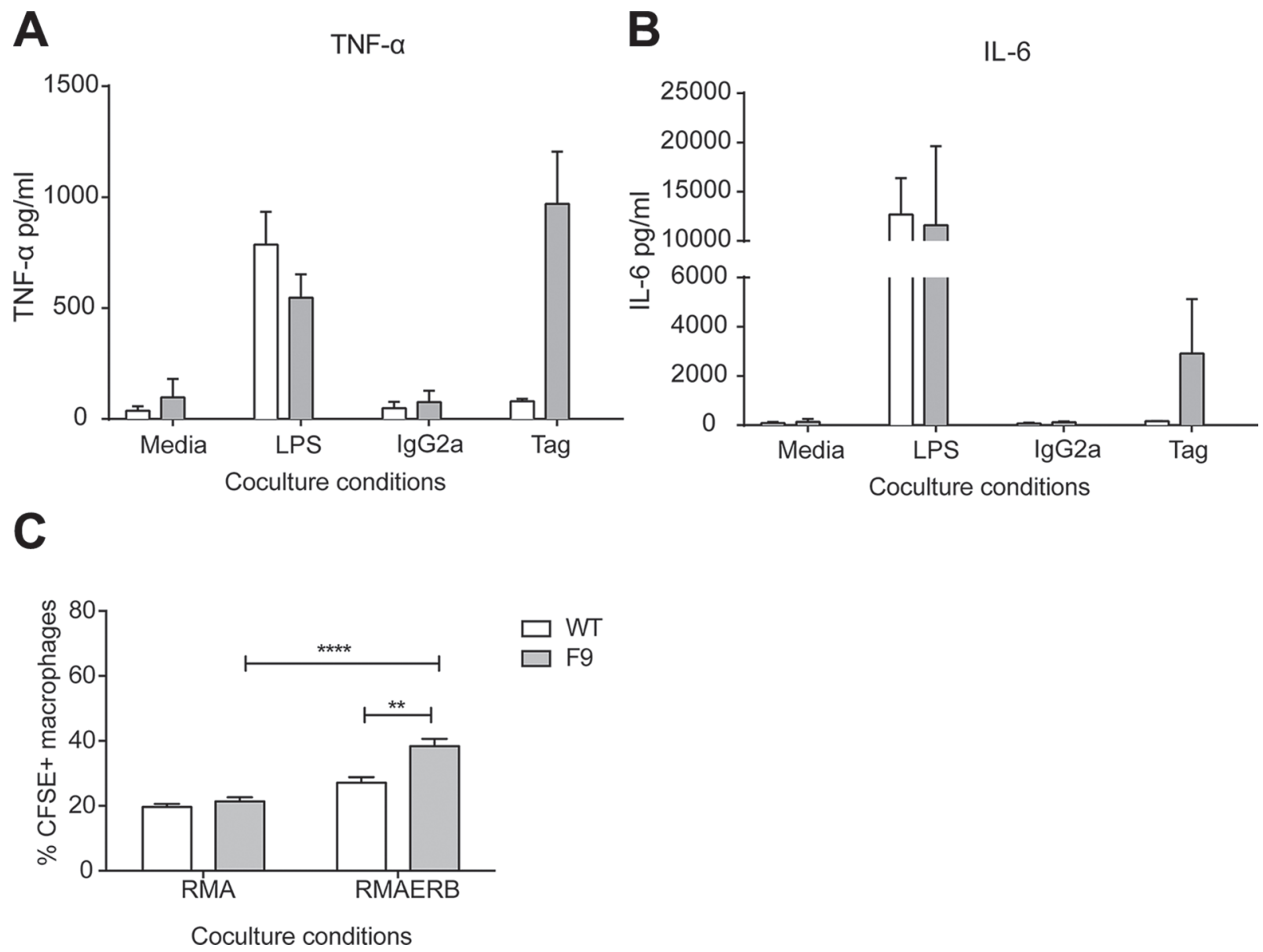

Figure 4: Antigen specific responses from $\mathbf{C A R}^{+}$monocytes. (A-B) Peritoneal exudate cells (PECs) from WT and vav-CAR mice were harvested and co-cultured overnight in the following conditions; media, LPS, immobilized IgG2a or $\alpha$-c-myc tag. Supernatant was harvested the following day and assessed for TNF- $\alpha$ and IL- 6 secretion by CBA. Data represents mean \pm SEM for 2 independent experiments. (C) WT and vav-CAR mice were injected intraperitoneally with thioglycollate and PECs harvested 4 days later. Tumor targets were labeled with CFSE and co-cultured with PECs at a 1:1 ratio for an hour at $37^{\circ} \mathrm{C}$. Cells were harvested and stained for FACs. Macrophages were gated and analysed for the proportion of $\mathrm{CFSE}^{+}$cells in the population. Data represents mean $\pm \mathrm{SEM}$ for 3 independent experiments (total of 6 mice/strain) $* * p<0.003, * * * * p<0.0001$. 


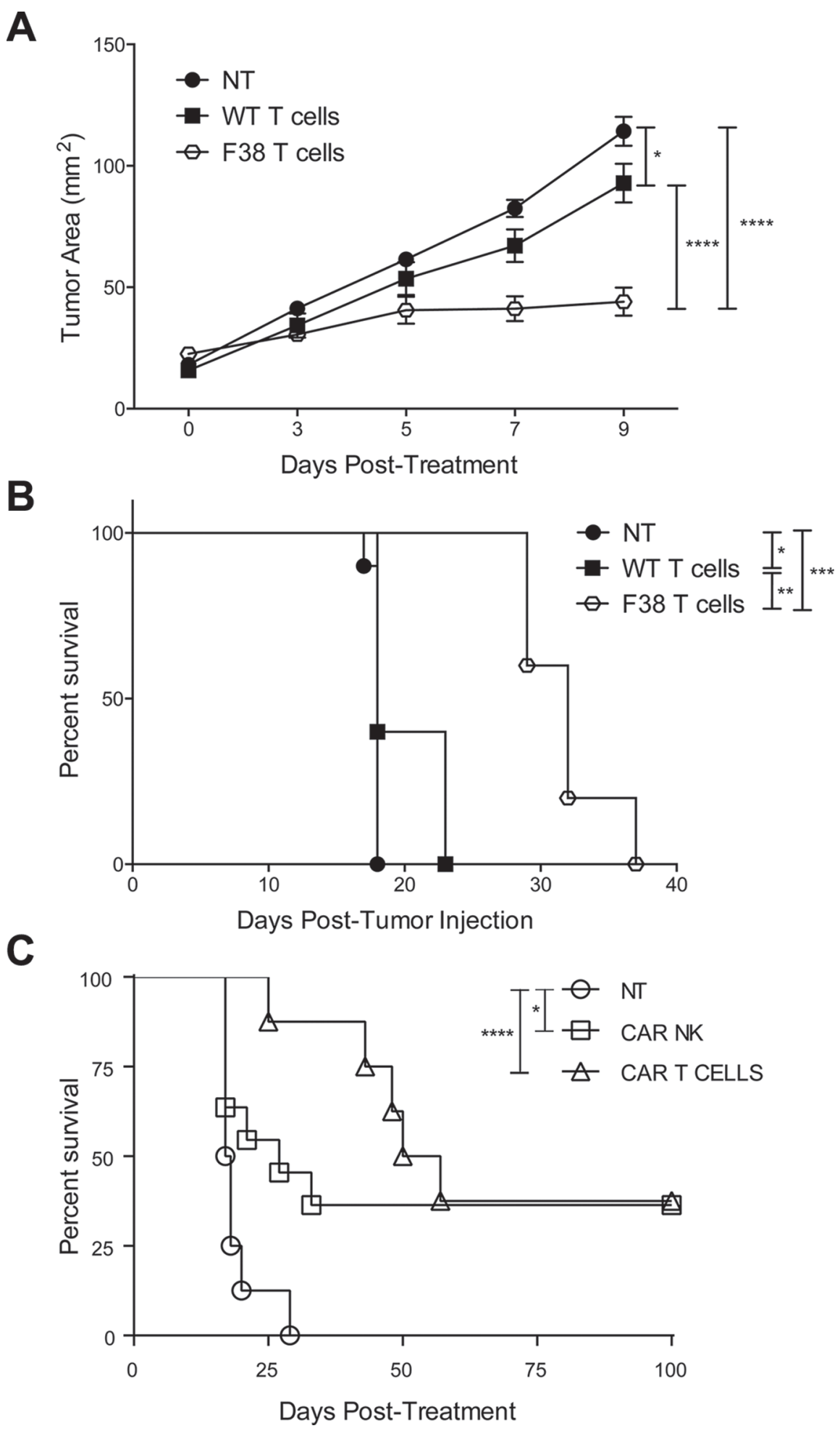

Figure 5: Adoptive transfer of CAR T or CAR NK cells into Her2 tumor bearing mice impedes tumor growth and provides a survival advantage. $(A-B) 1 \times 10^{5}$ E0771ERB cells were injected subcutaneously into Her 2 transgenic mice. On day 7 post tumor inoculation, mice were sublethally irradiated with $5 \mathrm{~Gy}$ irradiation. In vitro activated $\mathrm{T}$ cells were adoptively transferred intravenously on days 7, 8 and 14 post tumor inoculation. Exogenous rhIL-2 was administered on the day of day 7 transfer and thereafter twice daily for 4 days post $\mathrm{T}$ cell transfer. Data represents one experiment, 5 mice per treated group, 10 mice for non-treated. ${ }^{*} p<0.05$, ${ }^{* *} p<0.004, * * * p<0.0005, * * * * p<0.0001$. (C) $1 \times 10^{6}$ RMAERB cells were injected into the peritoneum of WT mice. Adoptive transfer of $5 \times 10^{6}$ in vitro activated CAR NK cells or CAR T cells were delivered into the peritoneum on the same day. Non-treated mice served as a control. Mice were monitored for signs of sickness or an increase in stomach diameter and sacrificed accordingly. Data represents one experiment, 8 -11 mice/group. ${ }^{*} p<0.03,{ }^{* * * *} p<0.0001$. 
tumor eradication in this model. Previous studies have indicated the eradication of intraperitoneal RMA tumor challenges are facilitated through the combined efforts of $\mathrm{CD}^{+} \mathrm{T}$ cells and NK cells [34]. As the depletion of either CD8 or NK cells completely abrogated the survival advantage observed in immunocompetent mice, we explored whether the depletion of both $\mathrm{CD} 8^{+} \mathrm{T}$ cells and NK cells would further reduce the survival time in F38 $v a v$-CAR mice. Indeed, we observed a reduction in the median survival time of mice treated with the combination depletion (NK cells and $\mathrm{CD}^{+} \mathrm{T}$ cells) compared to those treated with the single depletion (24 days for combination, 27 days for NK, 35 for CD8).

Taken together, the data indicates that the presence of NK cells and macrophages as well as both $\mathrm{CD} 4^{+}$and $\mathrm{CD}^{+} \mathrm{T}$ cells are integral in the inhibition of Her $2^{+}$tumors in the vav-CAR model.

\section{DISCUSSION}

Despite the recent success using adoptively transferred CAR-expressing CTLs in hematological cancers, further work is required in order to gain similar levels of success in other cancer types. There is mounting evidence demonstrating the role for other immune cell types in adoptive immunotherapy, with numerous studies reporting enhanced anti-tumor effects with the co-transfer of unmodified or genetically modified CTLs in addition to other helper immune subsets $[11-13,15]$. However, due to current limitations in genetic modification techniques, the role and function of other immune subsets when expressing a CAR have yet to be fully explored. We developed a novel mouse model utilizing a pan-hematopoietic promoter to drive the expression of a CAR directed against the tumor antigen ErbB2 within most immune subsets. Using this model, we were able to demonstrate the ability of the $v a v$-promoter in driving CAR expression throughout multiple immune lineages and subsets.

The curative potential of CAR expressing T cells has been demonstrated and well characterized in both mouse models and in clinical trials [35]. Despite similar methods of activation and similar ratios of CD4 to CD8 T cells, we observed almost a ten-fold difference in TNF- $\alpha$, IL- 6 and IFN- $\gamma$ released from F9 T cells compared to F38 T cells in response to tumor cells $24 \mathrm{JKERB}$. Whole genome analysis previously revealed F9 harboured almost 270 copies of the vav-CAR transgene, while F38 only had 7 copies [29]. This difference in gene dosage and the number of receptors present would have likely increased the strength of the interaction between the CAR and its target and subsequently, the strength of the downstream signal. This may have thus impacted the function of these cells, and whether they were indeed primed for cytotoxicity or cytokine secretion [36]. Therefore, we hypothesize that this may have accounted for the difference observed in cytokine secretion between the two founders. Indeed while CAR T cells from both strains of vav-CAR mice were able to mediate antigen specific cytotoxicity against the tumor line, 24JK, a higher level of background killing (antigen independent) was observed from F9 mice, indicating potentially a difference in the activation levels and baseline cytotoxicity of these T cells.

The use of CAR expressing murine NK cells in adoptive immunotherapy has not been extensively studied. Previous work from our lab has demonstrated the potential for primary murine NK cells genetically modified with a CAR to exhibit antigen specific anti-tumor function [22]. In the current study, when comparisons between the level of cytotoxicity against RMAERB from WT and CAR

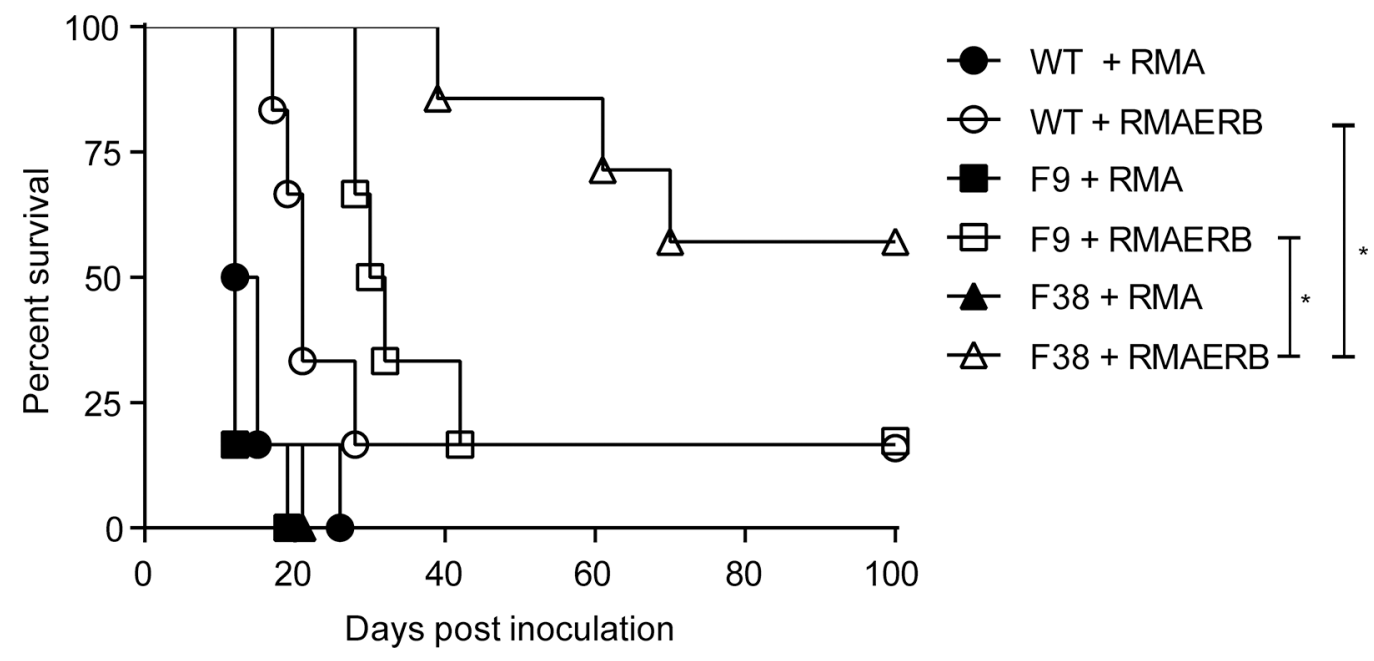

Figure 6: F38 mice can mount an effective immune response against RMAERB tumors in vivo. Naïve WT, F9 and F38 mice were inoculated with $1 \times 10^{6}$ RMA or RMAERB cells in the peritoneum and monitored for survival. Mice were sacrificed when showing signs of sickness or stomach diameter had increased by $30 \%$, indicative of tumor growth. Data represents one of two independent experiments, 5-7 mice/group per experiment. ${ }^{*} p<0.03$. 
A

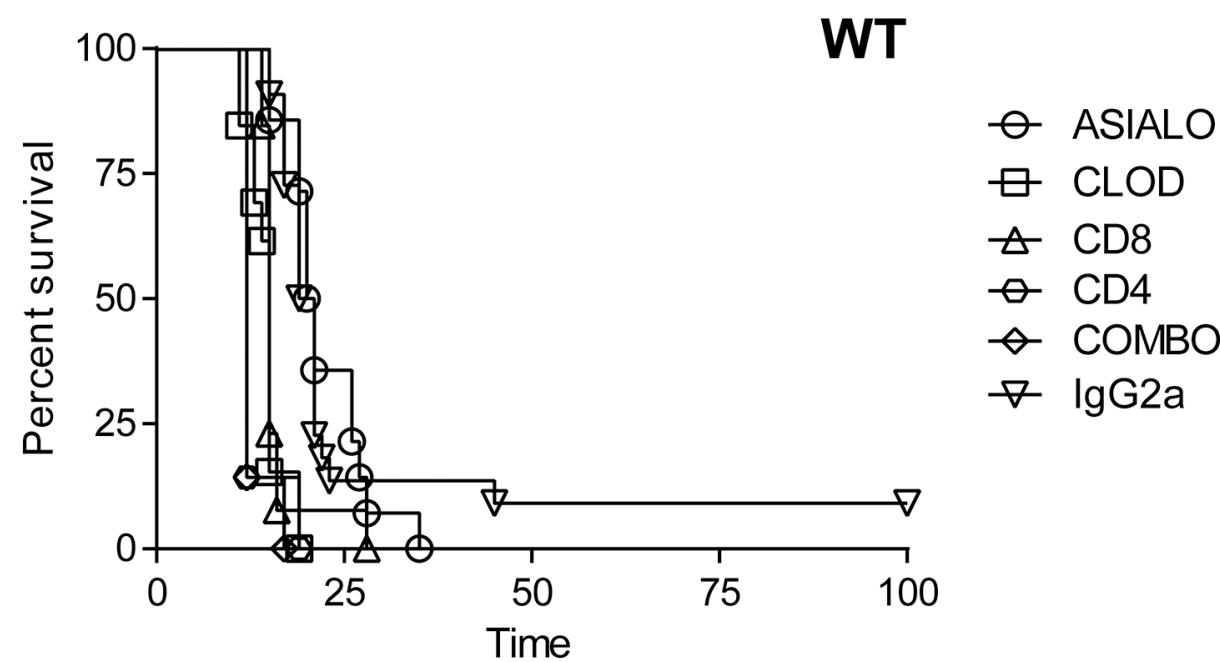

B

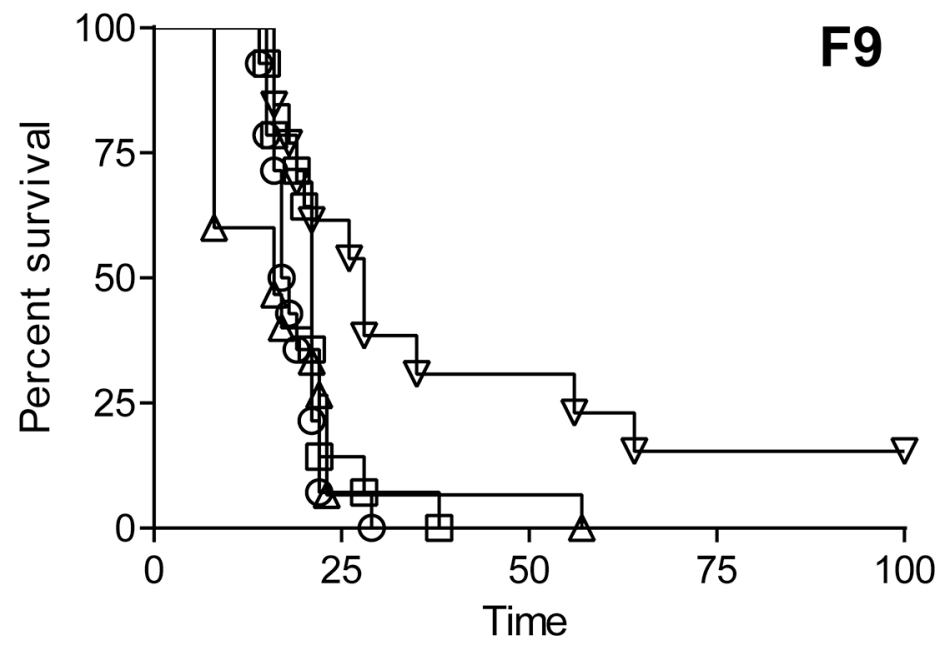

C

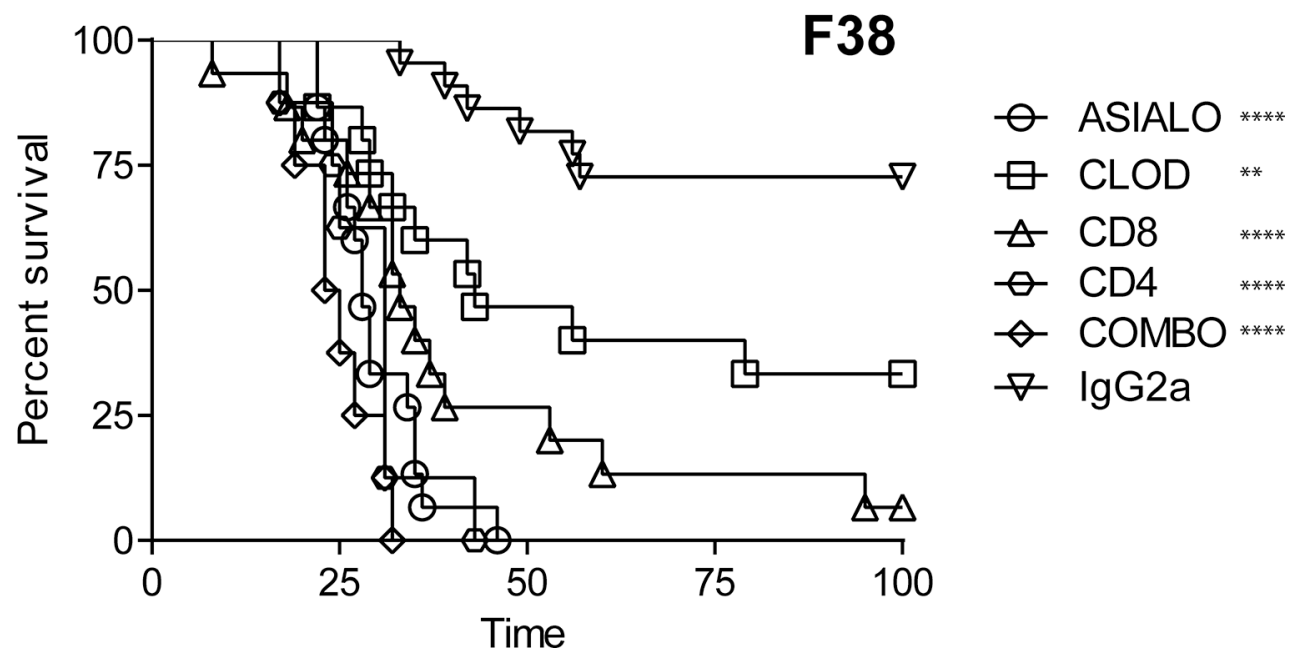

Figure 7: A role for $\mathbf{C A R}^{+}$lymphoid and myeloid cells in tumor rejection in $\mathbf{F 3 8}$ mice. (A) WT, (B) F9 and (C) F38 mice were depleted of certain immune subsets with the following reagents; Asialo GM1 (NK cells), Clodronate Liposomes (Clod) (Phagocytes, macrophages), $\alpha$-CD8 (CD8 ${ }^{+} \mathrm{T}$ cells), $\alpha$-CD4 (CD4 ${ }^{+} \mathrm{T}$ cells), combination (COMBO) (Asialo GM1 and $\alpha$-CD8) or IgG2a (irrelevant antibody control). Primary depletions were performed 2 days prior and on the day of tumor inoculation. Weekly maintenance depletions were performed for 6-7 weeks post tumor inoculation. Mice were sacrificed when showing signs of sickness or stomach diameter had increased by $30 \%$, indicative of tumor growth. Data represents 2-3 independent experiments, 6-20 mice/group in total. Statistical significance comparing treatment group versus IgG2a treatment supplied on the figure. Comparisons of COMBO vs CD8, $p=0.006$, COMBO vs ASIALO, $p=0.052 .{ }^{*} p<0.03,{ }^{* *} p<0.008, * * * * p<0.0001$. 
NKs were drawn, we observed a significantly higher level of killing from CAR NKs compared to WT NKs at all four effector to target ratios, however we also observed a higher level of background killing from CAR NKs against the RMA targets. Therefore, the genetic modification of NK cells with a CAR has been shown to increase their anti-tumor potential but at the price of a higher basal level of cytotoxicity. Careful consideration must be taken to ensure the cytotoxic functions are restricted to antigen specific targets in future clinical trials.

Given the difficulties in isolating and expanding numerous subsets to determine their anti-tumor function, we decided to approach this in a different manner by challenging vav-CAR mice intraperitoneally with the RMAERB cell line, and observe whether the absence of specific immune subsets would increase or decrease the survival outcome. The differences in survival between F9 and F38 mice when challenged with RMAERB cells indicated the necessity for lymphocytes, in particular $\mathrm{CD}^{+} \mathrm{T}$ cells for long-term survival.

Surprisingly, we observed a significant reduction in the survival of macrophage depleted (clodrolip treated) mice, in the F38 strain, with a reduction in median survival time from 100 to 43 days, suggesting a role for macrophages in tumor inhibition. There are numerous functions that macrophages could play to contribute to tumor rejection in this model; including phagocytosis, antigen presentation or cytokine secretion to activate other effector cells. However, the scope of this study did not extend as far to determine their exact role in this tumor model. While our in vitro and in vivo data indicates a potential role for CAR expressing macrophages in adoptive immunotherapy, we cannot rule out the complexity of the immune compartment in the peritoneum. The introduction of tumor cells in the peritoneum would result in inflammation at the injection site, and subsequently attract various immune responders. As clodrolip does not specifically target macrophages, but rather phagocytic cells, it is likely that clodrolip treatment in our experiment depleted numerous phagocytic subsets. A macrophage specific depletion, such as crossing the vavCAR mice with CD11b-DTR transgenic mice [37] may be useful to determine the exact contributions of CARmacrophages in this model. In addition, the polarisation and phenotype of tumor-infiltrating macrophages, be they M1 or M2, can greatly increase or decrease the antitumor efficacy and the function of these cells, respectively $[38,39]$. Future studies using this model may benefit from specifically depleting tumor-promoting macrophages (M2) or polarising them into a more anti-tumor phenotype (M1). Overall, this data suggest that a coordinated response is required from multiple arms of the immune system for efficient anti-tumor function, and indicates a potential role for CAR expressing macrophages in adoptive immunotherapy.
In our studies into the contributions of cell types to antitumor activity, we used a depleting antibody specific for CD8-alpha (to deplete T cells) and clodrolip (to deplete macrophages). However, since CD8-alpha is also expressed on a proportion of dendritic cells (DCs) and clodrolip also depletes some DCs, we cannot rule out a contribution from DCs in the effect. It would be informative in future experiments to use more specific reagents, for example using an anti CD8-beta antibody that does not deplete DCs. Strikingly, the depletion of $\mathrm{CD}^{+} \mathrm{T}$ cells had a less dramatic effect on the survival of F38 mice compared to the depletion of NK cells or $\mathrm{CD}^{+}$ $\mathrm{T}$ cells. As the percentage of NK cells and the subsequent proportion of $\mathrm{CAR}^{+} \mathrm{NK}$ cells is similar between both $\mathrm{F} 9$ and F38 mice (F9 $1.96 \pm 0.22$ total NKs, 56.71\% CAR ${ }^{+}$, $\mathrm{F} 383.08 \pm 0.15$ total $\mathrm{NKs}, 44.93 \% \mathrm{CAR}^{+}$, mean $\pm \mathrm{SEM}$, proportion of $\mathrm{CAR}^{+} \mathrm{NKs}$ in total population, [29]), and we observed significant differences in survival times in the RMAERB challenge (Figure 6), this indicates that the NK cells themselves may not be playing a direct cytotoxic role in this tumor model. Rather, the reduction in $\mathrm{CAR}^{+} \mathrm{CD}^{+}$ $\mathrm{T}$ cell population in the F9 model suggests that $\mathrm{CD}^{+}$ $\mathrm{T}$ cells are integral for tumor rejection, and perhaps the presence of $\mathrm{CAR}^{+} \mathrm{CD}^{+} \mathrm{T}$ cells or $\mathrm{CAR}^{+} \mathrm{NKs}$ are required to prime and coordinate the overall immune response, providing sufficient activation either through direct contact or via cytokine secretion to facilitate the actions of $\mathrm{CAR}^{+} \mathrm{CD}^{+} \mathrm{T}$ cells. As the immune system functions on a finite balance, one could postulate the depletion of an integral anti-tumor effector such as a $\mathrm{CD}^{+} \mathrm{T}$ cell, $\mathrm{CD} 4^{+} \mathrm{T}$ cell or NK cell may be sufficient to offset this balance, and thus have a greater effect on the activity of the remaining immune system than just the absence of the cell itself.

In line with our hypothesis, the depletion of both NK cells and $\mathrm{CD}^{+} \mathrm{T}$ cells together had the greatest effect in reducing the survival time in this tumor model (combo 24 days, $\alpha$-CD4 31 days, $\alpha$-CD8 35 days, Asialo 27 days, Clodrolip 43 days, IgG2a control $>100$ days), suggesting that a synergistic effect may be occurring. However further investigation to delineate the exact role for CAR NKs and CAR T cells are required. The vav-CAR model provides the perfect platform to enable testing of such combinations, allowing for the isolation of stably expressing CAR NK cells and CAR T cells without the requirement for genetic modification. Future experiments with this model will aim to dissect the potential of these two immune cells and in particular, whether adoptive transfer of CAR T cells and NK cells can synergise and what factors are required for enhancing $\mathrm{CAR}^{+} \mathrm{CD}^{+} \mathrm{T}$ cell function.

One caveat of CAR T cell therapy is the "ontarget/off-tumor" effect and the subsequent side effects and toxicity that ensue $[35,40]$. As CAR-modified NK cell lines have proven to be safe and are able to mediate cytotoxicity in a highly antigen dependent manner 
$[25,41,42]$, it may be of interest to combine primary CAR modified T cells with CAR modified NK-92 cells in future studies. Not only would this reduce the time required for ex vivo expansion of the primary CAR T cells (thus enabling the use of "younger" $T$ cells [43-45]) but a reduction in the number of $\mathrm{T}$ cells transferred may also correlate in a reduction in "on-target/off-tumor" effects $[4,46]$. Further pre-clinical analysis must be performed to determine the anti-tumor potential of the combination of these two subsets. The use of genetically modified IL-15 secreting NK-92 cells or IL-2/IL-15 independent NK-92 cell lines may be used in these studies to alleviate any potential competition for cytokines between the two cell subsets [47-49]. In addition, the genetic modification of this cell line to secrete cytokines or factors, which enhance $\mathrm{T}$ cell survival and proliferation may also reduce the need to deliver high doses of exogenous cytokines alongside the adoptive transfer.

There have been recent studies highlighting the potential to genetically modify hematopoietic stem cells (HSCs) with CARs to allow for a long term and continuous source of CAR expressing immune cells [50]. The many advantages of CAR modified HSCs include the potential for a younger, more naive population of CAR expressing $\mathrm{T}$ cells with a greater chance of developing into long term memory cells. In addition, as the generation of NK cells and myeloid cells with CARs would be relatively faster than the development of the adaptive immune system, this may provide early protection against residual tumors during the time taken for thymopoiesis of CAR bearing $T$ cells in the stem cell setting $[17,51]$. The feasibility of moving this type of therapy to the clinic (after vigorous pre-clinical studies) would be relatively straight forward, where CAR modified HSCs would be transplanted after conditioning treatments, such as in a normal bone marrow transplant [50]. Several mouse models, using TCR, CAR or 'universal receptor' (UR) modified HSCs have been developed in order to study the function of genetically modified myeloid cells and other non-T lymphocytes $[16,17,50-53]$. The development of the $v a v$-CAR mouse model may contribute greatly to this field of adoptive immunotherapy. We have demonstrated in our previous studies the expression of the anti-Her2 CAR is present on multiple immune subsets, including those of myeloid origin. The use of vav-CAR HSCs from transgenic mice would eliminate the laborious task of genetically modifying HSCs with CARs, and furthermore, ensure stable and consistent transgene dosages between experiments.

The vav-CAR mouse model is a novel and unique tool to further study the anti-tumor potential of a range of immune subsets when genetically modified to express a CAR. We have previously demonstrated the ability of the vav promoter to drive the expression of a CAR throughout multiple immune subsets [29]. In this study, we demonstrate the anti-tumor function of multiple immune subsets from these mice. Vav-CAR mice challenged with Her2 expressing tumors were able to mount an effective anti-tumor immune response, resulting in tumor eradication and long term survival, and this was shown to be dependent on both NK cells and CD8 ${ }^{+}$ $\mathrm{T}$ cells with an important role also shown for $\mathrm{CD}^{+} \mathrm{T}$ cells and macrophages. In future studies the vav-CAR mouse will enable testing the anti-tumor function of various adoptively transferred immune cell combinations. It remains to be established whether all effectors in these combinations require the ability to recognise the tumor antigen or if recognition by a key player, such as a CTL, may be sufficient to activate and coordinate with other unmodified effector cells. Elucidating the mechanisms between different genetically modified immune subsets may lead to significantly improving the therapeutic application of adoptive immunotherapy, particular in the solid cancer setting.

\section{MATERIALS AND METHODS}

\section{Cell culture and mouse models}

The murine 24JK fibrosarcoma cell line [54] was kindly donated by Dr. Patrick Hwu (NIH, Bethesda, MD) and maintained at $37^{\circ} \mathrm{C}$ in $5 \% \mathrm{CO}_{2}$ in RPMI- 1640 media supplemented with $5 \%$ heat-inactivated fetal calf serum (FCS) with $2 \mathrm{mmol} / \mathrm{L}$ glutamine, $1 \mathrm{mmol} / \mathrm{L}$ sodium pyruvate, $0.1 \mathrm{mmol} / \mathrm{L}$ nonessential amino acids, $100 \mathrm{U} / \mathrm{mL}$ penicillin and $100 \mu \mathrm{g} / \mathrm{mL}$ streptomycin (Life Technologies). The murine breast adenocarcinoma cell line E0771 (LMC variant) was kindly donated by Professor Robin Anderson (Peter MacCallum Cancer Centre, Victoria, Australia) and maintained in RPMI with supplements as above. The murine RMA T cell lymphoma cell line was derived from the Rauscher murine leukemia virus-induced RBL-5 cell line and maintained at $37^{\circ} \mathrm{C}$ in $10 \% \mathrm{CO}_{2}$ in Dulbecco's modified Eagle medium (DMEM) supplemented as above [55]. All cell lines were previously retrovirally transduced with a retroviral vector encoding the cDNA for human Her2 [21]. Vav-CAR mice were generated and characterized as previously described [29]. Heterozygous mice were used unless stated. C57BL/6Her2 mice express human Her2 under the mouse WAP promoter [56, 57]. Mice were bred and maintained under specific pathogen-free conditions within the animal experimentation facility at the Peter MacCallum Cancer Centre. All mice experiments were performed following the Peter MacCallum Cancer Centre Animal Experimentation Ethics Committee guidelines.

\section{Flow cytometry}

Spleens from WT and vav-CAR mice were dissociated in phosphate-buffered saline (PBS) and processed into single cell suspensions through a $70 \mu \mathrm{m}$ 
filter. Splenocytes were treated with ammonium chloride potassium (ACK) lysis buffer to remove red blood cells. $5 \times 10^{5}$ splenocytes, in vitro activated cells and peritoneal exudate cells (PECs) were resuspended in Fc receptorblocking buffer (anti-mouse Fc $\gamma$ RII/Fc $\gamma$ RIII, clone $2.4 \mathrm{G} 2$ made in house from tissue culture supernatant) for 10 minutes prior to staining with the following antibodies; TCR $\beta$-PerCP-Cy5.5 (clone H57-597), CD3-e450 (clone 17A2), CD4-APC-eF780 (clone RM4-5), CD8-Pe-Cy7 (clone 53-6.7), CD11B-APC (clone M1/70), F4/80-Pe-Cy7 (clone BM8), NK1.1-Pe-Cy7 (clone PK136), CD49b-APC (clone DX5) (all from eBioscience, California, USA), a-c-myc-tag Alexa488 (clone 9B11) (Cell Signaling, Massachusetts, USA ) or mouse immunoglobulin isotype IgG2a Alexa488 (Invitrogen, Scoresby, Australia).

\section{$T$ cell activation}

Splenocytes were dissociated into single cell suspensions and treated with ACK lysis buffer as above. Remaining leukocytes were resuspended at $2.5 \times 10^{7}$ cells/well in $5 \mathrm{ml}$ of RPMI with additives (see cell culture methods section) and were activated overnight with $\alpha-C D 3 \varepsilon$ (clone $145-2 \mathrm{C} 11)(500 \mathrm{ng} / \mathrm{ml})$ and $\alpha-\mathrm{CD} 28$ (clone 37.51) (500 ng/ml) (BD Bioscience) with recombinant human IL-2 (rhIL-2) (100 U/ml) and mouse IL-7 (mIL-7) $(2 \mathrm{ng} / \mathrm{ml})$ in $5 \% \mathrm{CO}_{2}$ at $37^{\circ} \mathrm{C}$. The cells were harvested the next day and centrifuged at $400 \mathrm{~g}$ for 4 minutes to remove activating antibodies. Cells were then resuspended in RPMI with additives including rhIL-2 (100 U/ml) and mIL-7 ( $2 \mathrm{ng} / \mathrm{ml}$ ). Functional assays and immunophenotyping were performed on days 5 to 7 post activation.

\section{NK isolation and expansion}

Spleens from WT and homozygous F38 mice were processed as above to produce single cell suspensions. No ACK lysis was performed. $5 \times 10^{7}$ splenocytes were resuspended in $500 \mu \mathrm{l}$ of Facs buffer (PBS $+2 \%$ FCS). NK cells were isolated by negative selection using the StemCell EasySep Mouse NK Cell Enrichment kit (StemCell) according to manufacturer's instructions. NK cells $\left(7 \times 10^{5}\right)$ were resuspended in $1 \mathrm{ml}$ of RPMI plus additives to a total of $20 \% \mathrm{FCS}$ in addition to $1000 \mathrm{IU} / \mathrm{ml}$ of rhIL-2 and $50 \mathrm{mM} \beta$-Mercaptoethanol (BME). On day 5 post isolation, $500 \mu \mathrm{l}$ of the NK culture was transferred to a new well and refreshed with RPMI plus additives in addition to BME and $100 \mathrm{IU} / \mathrm{ml}$ of rhIL-2. Functional assays were performed on day 7 post isolation.

\section{Cytometric bead array}

For T cells; $2 \times 10^{6}$ in vitro activated T cells were cultured overnight with the following conditions; media alone, immobilized $\alpha-C D 3 \varepsilon$ and $\alpha-C D 28$ (50 $\mathrm{ng} / \mathrm{ml}$ ), immobilized $\alpha-\operatorname{IgG} 2 \mathrm{a} \kappa$ (BD Bioscience), immobilized $\alpha$-c-myc tag (clone 9B11) (Cell signaling) or $1 \times 10^{6}$ tumor targets $24 \mathrm{JK}$ or $24 \mathrm{JKERB}$. For macrophages; naïve peritoneal exudate cells (PECs) from WT and vav-CAR mice were harvested in the absence of thioglycollate stimulation. $1 \times 10^{5}$ PECs were co-cultured overnight with media (DMEM) containing either lipopolysaccharide (LPS) at $(5 \mu \mathrm{g} / \mathrm{ml})$, or immobilized $\alpha$-c-myc tag or IgG2a at $(0.5 \mu \mathrm{g} / \mathrm{ml})$. For NKs; $1.25 \times 10^{5}$ in vitro activated $\mathrm{NK}$ cells were co-cultured with media alone, or with positive stimulation via phorbol 12-myristate 13-acetate (PMA) and ionomycin (50 $\mathrm{ng} / \mu \mathrm{l}$ and $1 \mu \mathrm{g} / \mathrm{ml}$ respectively), or immobilized $\alpha$-IgG2a $\kappa$, or immobilized $\alpha$-c-myc tag or tumor targets $24 \mathrm{JK} / 24 \mathrm{JKERB}$ or RMA/RMAERB at a $1: 1$ ratio $\left(1.25 \times 10^{5}\right.$ cells of each). Supernatant was harvested the next day and analysed by cytometric bead array (CBA) for the following cytokines and chemokines; IL-4, IL-2, IL-17A, TNF- $\alpha$, IL-6 and IFN- $\gamma$ for T cells and IL-17A, TNF- $\alpha$ and IFN- $\gamma$ for NK cells using the Facs Verse (BD Bioscience). Results were analysed using the FCAP Array Software (BD Bioscience).

\section{Phagocytosis assay}

Methodology to detect macrophage phagocytosis was adapted from [58]. WT and vav-CAR mice were injected with $1 \mathrm{ml}$ of thioglycollate intraperitoneally. PECs were harvested on day 4 by intraperitoneal wash. Tumor cells $\left(2.5 \times 10^{5} \mathrm{RMA} / \mathrm{ERB}\right)$ were labeled with carboxyfluorescein succinimidyl ester (CFSE) and co-cultured with $2.5 \times 10^{5} \mathrm{PECs}$ for 1 hour at $37^{\circ} \mathrm{C}$ in $10 \% \mathrm{CO}_{2}$ in a 24 well plate. After 1 hour, the plate was centrifuged at $400 \mathrm{~g}$ for 4 minutes. The cells were incubated with Fc receptor block for 10 minutes, stained with F4/80-Pe-Cy7 (clone BM8) and CD11B-APC (clone $\mathrm{M} 1 / 70$ ) (eBioscience) and analysed by flow cytometry. Macrophages were gated on as being F4/80 $0^{+}$and $\mathrm{CD}_{11 \mathrm{~b}^{+}}$ and the proportion and mean fluorescence intensity (MFI) of CFSE positive macrophages was assessed as a measure of phagocytosis.

\section{Chromium release assay}

Tumor targets $24 \mathrm{JK}$ and 24JKERB or RMA and RMAERB were labeled with ${ }^{51} \mathrm{Cr}$ and plated at either $5 \times 10^{3}$ or $2 \times 10^{4}$ cells/well in a 96-well U-bottom plate. Activated effector cells were co-incubated at varying effector to target ratios $(1: 1,5: 1,10: 1,20: 1,40: 1)$ and incubated for 4 hours at $37^{\circ} \mathrm{C}$ in $5 \% \mathrm{CO}_{2}$. Specific chromium release was determined by the following equation;

( $\%$ chromium release - $\%$ spontaneous chromium release) $\times 100$

$(\%$ total chromium release - \% spontaneous chromium release)

with total chromium release determined by the addition of sodium dodecyl sulphate (SDS). The level of 
chromium release was determined using a Wallac Wizard 1470 automatic gamma counter (Amersham).

\section{In vivo adoptive transfer}

Human Her2 $2^{+}$transgenic mice were injected subcutaneously (SC) with $1 \times 10^{5}$ E0771ERB cells [56]. The mice were then sub-lethally irradiated with 5 Gy irradiation 7 days later and treated with $3-5 \times 10^{6} \mathrm{~T}$ cells intravenously on day 7, 8 and 14. Exogenous IL-2 (50,000 $\mathrm{IU} / 200 \mu \mathrm{l})$ was administered intraperitoneally on day 7 and thereafter twice a day for four days post treatment (9 doses total). Tumors were measured twice a week and mice were euthanized when tumors exceeded the ethical limit of $150 \mathrm{~mm}^{2}$. For NK and T cell adoptive transfer, C57BL/6 mice were injected intraperitoneally with $1 \times 10^{6}$ RMAERB cells and then treated on the same day with $5 \times 10^{6}$ effector cells intraperitoneally. Non-treated mice served as controls. Mice were euthanized when showing signs of illness or when abdomen diameter had increased over $30 \%$.

\section{RMA challenge and in vivo depletion studies}

RMA or RMAERB cells were washed twice with PBS and resuspended at $5 \times 10^{6}$ cells $/ \mathrm{ml}$. Naïve C57BL $/ 6$ mice or homozygous vav-CAR mice were injected with $1 \times 10^{6}$ tumor cells $(200 \mu \mathrm{l})$ using a $26 \mathrm{G}$ needle into the peritoneum and monitored for signs of illness and survival. Mice were euthanized when showing signs of illness or when the abdomen diameter had increased over $30 \%$. For depletion studies, mice received primary depletion 2 days prior and on the day of tumor inoculation using the following antibodies; Asialo GM1 (100 $\mu \mathrm{l} /$ mouse) (Wako), $\alpha$-CD8 (clone YTS169.4) at $300 \mu \mathrm{g} /$ mouse, clodronate liposomes (Clodrolip) at $250 \mu \mathrm{g} /$ mouse, $\alpha$-CD4 (GK1.5) at $300 \mu \mathrm{g} /$ mouse, or an irrelevant antibody rat IgG2a (clone 2A3) at $300 \mathrm{mg} /$ mouse (clone 2A3). Weekly maintenance depletions were administered with the following concentrations; Asialo GM1 at $100 \mu \mathrm{l} /$ mouse, $\alpha$ CD8 at $100 \mu \mathrm{g} /$ mouse, Clodrolip at $250 \mu \mathrm{g} /$ mouse, $\alpha$-CD4 at $100 \mu \mathrm{g} /$ mouse or rat IgG2a irrelevant antibody at $100 \mu \mathrm{g} / \mathrm{mouse}$ for the first 6-7 weeks post tumor inoculation. Mice treated with the combination received both $\alpha-\mathrm{CD} 8$ and Asialo GM1 at the same concentration as the single treatments. Surviving mice were rechallenged with $1 \times 10^{6}$ RMAERB cells injected into the peritoneum at day 60 and monitored for survival.

\section{Statistics}

Statistical significance was analysed using an unpaired Student's $T$ test. Tumor growth measurements in Figure 5 were analysed using a two-way ANOVA.

\section{FINANCIAL SUPPORT}

This work was supported by grants from the Cancer Council of Victoria, Australia (1066554), The Peter MacCallum Cancer Centre Foundation, and the National Health and Medical Research Council (NHMRC) of Australia (1103352). CSMY was supported by an Australian Postgraduate Award and Cancer Therapeutics Australia Scholarship. RWJ was supported by Senior Principal Research Fellowship from the NHMRC. MHK and PKD were supported by Senior Research Fellowships from the NHMRC.

\section{CONFLICTS OF INTEREST}

The authors declare that they have no conflicts of interest

\section{Authors' contributions}

CSMY conceived, designed and performed experiments, acquired and interpreted data and wrote the manuscript; LBJ, CD assisted in experiments; HMP, RWJ, JAT provided intellectual input into study design and data interpretation; PKD, MHK conceived the study and designed experiments.

\section{REFERENCES}

1. Maude SL, Frey N, Shaw PA, Aplenc R, BarrettDM, Bunin NJ, Chew A, Gonzalez VE, Zheng Z, Lacey SF, Mahnke YD, Melenhorst JJ, Rheingold SR, et al. Chimeric antigen receptor T cells for sustained remissions in leukemia. The New England journal of medicine. 2014; 371:1507-1517.

2. Lee DW, Kochenderfer JN, Stetler-Stevenson M, Cui YK, Delbrook C, Feldman SA, Fry TJ, Orentas R, Sabatino M, Shah NN, Steinberg SM, Stroncek D, Tschernia N, et al. $\mathrm{T}$ cells expressing CD19 chimeric antigen receptors for acute lymphoblastic leukaemia in children and young adults: a phase 1 dose-escalation trial. Lancet. 2015; 385:517-28. doi: 10.1016/S0140-6736(14)61403-3.

3. Porter DL, Levine BL, Kalos M, Bagg A, June CH. Chimeric Antigen Receptor Modified T Cells in Chronic Lymphoid Leukemia. New England Journal of Medicine. 2011; 365:725-733.

4. Grupp SA, Kalos M, Barrett D, Aplenc R, Porter DL, Rheingold SR, Teachey DT, Chew A, Hauck B, Wright JF, Milone $\mathrm{MC}$, Levine $\mathrm{BL}$, June $\mathrm{CH}$. Chimeric antigen receptor-modified $\mathrm{T}$ cells for acute lymphoid leukemia. N Engl J Med. 2013; 368:1509-1518. doi: 1510.1056/ NEJMoa1215134.

5. Zhang T, Cao L, Xie J, Shi N, Zhang Z, Luo Z, Yue D, Zhang Z, Wang L, Han W, Xu Z, Chen H, Zhang Y. 
Efficiency of CD19 chimeric antigen receptor-modified T cells for treatment of B cell malignancies in phase I clinical trials: a meta-analysis. Oncotarget. 2015; 6:33961-33971. doi: 10.18632/oncotarget.5582.

6. Kershaw MH, Westwood JA, Parker LL, Wang G, Eshhar Z, Mavroukakis SA, White DE, Wunderlich JR, Canevari S, Rogers-Freezer L, Chen CC, Yang JC, Rosenberg SA, et al. A phase I study on adoptive immunotherapy using genemodified T cells for ovarian cancer. Clin Cancer Res. 2006; 12:6106-6115.

7. Lamers CH, Sleijfer S, Vulto AG, Kruit WH, Kliffen M, Debets R, Gratama JW, Stoter G, Oosterwijk E. Treatment of metastatic renal cell carcinoma with autologous T-lymphocytes genetically retargeted against carbonic anhydrase IX: first clinical experience. J Clin Oncol. 2006; 24:e20-22.

8. Cheadle EJ, Gornall H, Baldan V, Hanson V, Hawkins RE, Gilham DE. CAR T cells: driving the road from the laboratory to the clinic. Immunol Rev. 2014; 257:91-106. doi: 110.1111/imr.12126.

9. Gilham DE, Debets R, Pule M, Hawkins RE, Abken H. CAR-T cells and solid tumors: tuning $T$ cells to challenge an inveterate foe. Trends Mol Med. 2012; 18:377-384. doi: 310.1016/j.molmed.2012.1004.1009.

10. Zhang Y, Ertl HC. Depletion of FAP + cells reduces immunosuppressive cells and improves metabolism and functions CD8+T cells within tumors. Oncotarget. 2016. doi: 10.18632/oncotarget.7818.

11. Chamoto K, Kosaka A, Tsuji T, Matsuzaki J, Sato T, Takeshima T, Iwakabe K, Togashi Y, Koda T, Nishimura T. Critical role of the Th1/Tc1 circuit for the generation of tumor-specific CTL during tumor eradication in vivo by Th1-cell therapy. Cancer Science. 2003; 94:924-928.

12. Marzo A, Kinnear B, Lake R, JJ F, Collins E, Robinson B, Scott B. Tumor-specific CD4+ T cells have a major "postlicensing" role in CTL mediated anti-tumor immunity. Journal of Immunology. 2000; 165:6047-6055.

13. Antony PA, Piccirillo CA, Akpinarli A, Finkelstein SE, Speiss PJ, Surman DR, Palmer DC, Chan CC, Klebanoff CA, Overwijk WW, Rosenberg SA, Restifo NP. CD8+ T cell immunity against a tumor/self-antigen is augmented by $\mathrm{CD} 4+$ $\mathrm{T}$ helper cells and hindered by naturally occurring $\mathrm{T}$ regulatory cells. Journal of Immunology. 2005; 174:2591-2601.

14. Moeller M, Kershaw M, Cameron R. Sustained antigenspecific antitumour recall response mediated by genemodified CD4+ T helper-1 and CD8+T cells. Cancer Research. 2007; 67:11428-11437.

15. Klug F, Prakash H, Huber PE, Seibel T, Bender N, Halama N, Pfirschke C, Voss RH, Timke C, Umansky L, Klapproth K, Schakel K, Garbi N, et al. Low-dose irradiation programs macrophage differentiation to an iNOS(+)/M1 phenotype that orchestrates effective $\mathrm{T}$ cell immunotherapy. Cancer cell. 2013; 24:589-602.

16. De Oliveira SN, Ryan C, Giannoni F, Hardee CL, Tremcinska I, Katebian B, Wherley J, Sahaghian A, Tu A,
Grogan T, Elashoff D, Cooper LJ, Hollis RP, et al. Modification of hematopoietic stem/progenitor cells with CD19-specific chimeric antigen receptors as a novel approach for cancer immunotherapy. Human gene therapy. 2013; 24:824-839.

17. Alajez NM, Schmielau J, Alter MD, Cascio M, Finn OJ. Therapeutic potential of a tumor-specific, MHC-unrestricted T-cell receptor expressed on effector cells of the innate and the adaptive immune system through bone marrow transduction and immune reconstitution. Blood. 2005; $105: 4583-4589$.

18. John LB, Devaud C, Duong CP, Yong CS, Beavis PA, Haynes NM, Chow MT, Smyth MJ, Kershaw MH, Darcy PK. Anti-PD-1 antibody therapy potently enhances the eradication of established tumors by gene-modified T cells. Clinical cancer research. 2013; 19:5636-5646.

19. Wang LX, Westwood JA, Moeller M, Duong CP, Wei WZ, Malaterre J, Trapani JA, Neeson P, Smyth MJ, Kershaw MH, Darcy PK. Tumor ablation by gene-modified T cells in the absence of autoimmunity. Cancer Res. 2010; 70:9591-9598.

20. Moeller M, Haynes NM, Kershaw MH, Jackson JT, Teng MW, Street SE, Cerutti L, Jane SM, Trapani JA, Smyth MJ, Darcy PK. Adoptive transfer of gene-engineered CD4+ helper T cells induces potent primary and secondary tumor rejection. Blood. 2005; 106:2995-3003.

21. Kershaw MH, Jackson JT, Haynes NM, Teng MW, Moeller M, Hayakawa Y, Street SE, Cameron R, Tanner JE, Trapani JA, Smyth MJ, Darcy PK. Gene-engineered T cells as a superior adjuvant therapy for metastatic cancer. J Immunol. 2004; 173:2143-2150.

22. Pegram HJ, Jackson JT, Smyth MJ, Kershaw MH, Darcy PK. Adoptive Transfer of Gene-Modified Primary NK Cells Can Specifically Inhibit Tumor Progression In Vivo. The Journal of Immunology. 2008; 181:3449-3455.

23. Topfer K, Cartellieri M, Michen S, Wiedemuth R, Muller N, Lindemann D, Bachmann M, Fussel M, Schackert G, Temme A. DAP12-Based Activating Chimeric Antigen Receptor for NK Cell Tumor Immunotherapy. J Immunol. 2015; 194:3201-3212.

24. Seidel D, Shibina A, Siebert N, Wels WS, Reynolds CP, Huebener N, Lode HN. Disialoganglioside-specific human natural killer cells are effective against drug-resistant neuroblastoma. Cancer Immunol Immunother. 2015; 64:621-34. doi: 10.1007/s00262-015-1669-5.

25. Chu J, Deng Y, Benson DM, He S, Hughes T, Zhang J, Peng Y, Mao H, Yi L, Ghoshal K, He X, Devine SM, Zhang X, et al. CS1-specific chimeric antigen receptor (CAR)engineered natural killer cells enhance in vitro and in vivo antitumor activity against human multiple myeloma. Leukemia. 2014; 28:917-927.

26. Ogilvy S, Metcalf D, Print CG, Bath ML, Harris AW, Adams JM. Constitutive Bcl-2 expression throughout the hematopoietic compartment affects multiple lineages and enhances progenitor cell survival. PNAS. 1999; 96: 14943-14948. 
27. Ogilvy S, Metcalf D, Gibson L, Bath ML, Harris AW, Adams JM. Promoter elements of vav drive transgene expression in vivo throughout the hematopoietic compartment. Blood. 1999; 94:1855-1863.

28. Ogilvy S, Elefanty AG, Visvader J, Bath ML, Harris AW, Adams JM. Transcriptional regulation of vav, a gene expressed throughout the hematopoietic compartment. Blood. 1998; 91:419-430.

29. Yong CS, Westwood JA, Schroder J, Papenfuss AT, von Scheidt B, Moeller M, Devaud C, Darcy PK, Kershaw MH. Expression of a Chimeric Antigen Receptor in Multiple Leukocyte Lineages in Transgenic Mice. PLoS One. 2015; 10:e140543. doi: 0140510.0141371/journal.pone.0140543. eCollection 0142015.

30. Liu H, Yang B, Sun T, Lin L, Hu Y, Deng M, Yang J, Liu T, Li J, Sun S, Jiao S. Specific growth inhibition of ErbB2expressing human breast cancer cells by genetically modified NK92 cells. Oncology reports. 2015; 33:95-102.

31. Zhang G, Liu R, Zhu X, Wang L, Ma J, Han H, Wang X, Zhang G, He W, Wang W, Liu C, Li S, Sun M, et al. Retargeting NK-92 for anti-melanoma activity by a TCRlike single-domain antibody. Immunology and cell biology. 2013; 91:615-624.

32. Boissel L, Betancur-Boissel M, Lu W, Krause DS, Van Etten RA, Wels WS, Klingemann H. Retargeting NK-92 cells by means of CD19- and CD20-specific chimeric antigen receptors compares favorably with antibodydependent cellular cytotoxicity. Oncoimmunology. 2013; 2:e26527.

33. Cerwenka A, Lanier LL. Natural killer cells, viruses and cancer. Nature reviews Immunology. 2001; 1:41-49.

34. Diefenbach A, Jensen ER, Jamieson AM, Raulet DH. Rae1 and $\mathrm{H} 60$ ligands of the NKG2D receptor stimulate tumour immunity. Nature. 2001; 413:165-171.

35. Duong CP, Yong CS, Kershaw MH, Slaney CY, Darcy PK. Cancer immunotherapy utilizing gene-modified T cells: From the bench to the clinic. Mol Immunol. 2015; 67:46-57. doi: 10.1016/j.molimm.2014.1012.1009.

36. Faroudi M, Utzny C, Salio M, Cerundolo V, Guiraud M, Muller S, Valitutti S. Lytic versus stimulatory synapse in cytotoxic $\mathrm{T}$ lymphocyte/target cell interaction: manifestation of a dual activation threshold. Proc Natl Acad Sci U S A. 2003; 100:14145-14150.

37. Cailhier JF, Partolina M, Vuthoori S, Wu S, Ko K, Watson S, Savill J, Hughes J, Lang RA. Conditional macrophage ablation demonstrates that resident macrophages initiate acute peritoneal inflammation. J Immunol. 2005; 174:2336-2342.

38. Devaud C, Westwood JA, John LB, Flynn JK, PaquetFifield S, Duong CP, Yong CS, Pegram HJ, Stacker SA, Achen MG, Stewart TJ, Snyder LA, Teng MW, et al. Tissues in different anatomical sites can sculpt and vary the tumor microenvironment to affect responses to therapy. Mol Ther. 2014; 22:18-27.

39. Khan AN, Kolomeyevskaya N, Singel KL, Grimm MJ, Moysich KB, Daudi S, Grzankowski KS, Lele S, Ylagan L,
Webster GA, Abrams SI, Odunsi K, Segal BH. Targeting myeloid cells in the tumor microenvironment enhances vaccine efficacy in murine epithelial ovarian cancer. Oncotarget. 2015; 6:11310-11326. doi: 10.18632/ oncotarget.3597.

40. Stauss HJ, Morris EC. Immunotherapy with gene-modified T cells: limiting side effects provides new challenges. Gene Ther. 2013; 20:1029-1032. doi: 1010.1038/gt.2013.1034.

41. Uherek C, Tonn T, Uherek B, Becker S, Schnierle B, Klingemann HG, Wels W. Retargeting of natural killer-cell cytolytic activity to ErbB2-expressing cancer cells results in efficient and selective tumor cell destruction. Blood. 2002; 100:1265-1273.

42. Schonfeld K, Sahm C, Zhang C, Naundorf S, Brendel C, Odendahl M, Nowakowska P, Bonig H, Kohl U, Kloess S, Kohler S, Holtgreve-Grez H, Jauch A, et al. Selective inhibition of tumor growth by clonal NK cells expressing an ErbB2/HER2-specific chimeric antigen receptor. Mol Ther. 2015; 23:330-338. doi: 310.1038/mt.2014.1219.

43. Hombach AA, Chmielewski M, Rappl G, Abken H. Adoptive immunotherapy with redirected $\mathrm{T}$ cells produces CCR7- cells that are trapped in the periphery and benefit from combined CD28-OX40 costimulation. Hum Gene Ther. 2013; 24:259-269. doi: 210.1089/hum.2012.1247.

44. Klebanoff CA, Gattinoni L, Torabi-Parizi P, Kerstann K, Cardones AR, Finkelstein SE, Palmer DC, Antony PA, Hwang ST, Rosenberg SA, Waldmann TA, Restifo NP. Central memory self/tumor-reactive CD8 $+\mathrm{T}$ cells confer superior antitumor immunity compared with effector memory T cells. Proceedings of the National Academy of Sciences of the United States of America. 2005; 102:9571-9576.

45. Hombach AA, Abken H. Young T Cells Age During a Redirected Anti-Tumor Attack: Chimeric Antigen ReceptorProvided Dual Costimulation is Half the Battle. Front Immunol. 2013; 4:135.(doi):10.3389/fimmu.2013.00135. eCollection 02013 .

46. Morgan RA, Yang JC, Kitano M, Dudley ME, Laurencot CM, Rosenberg SA. Case report of a serious adverse event following the administration of $\mathrm{T}$ cells transduced with a chimeric antigen receptor recognizing ERBB2. Mol Ther. 2010; 18:843-851.

47. Nagashima S, Mailliard R, Kashii Y, Reichert TE, Herberman RB, Robbins P, Whiteside TL. Stable transduction of the interleukin-2 gene into human natural killer cell lines and their phenotypic and functional characterization in vitro and in vivo. Blood. 1998; 91:3850-3861.

48. Zhang J, Sun R, Wei H, Tian Z. Characterization of interleukin-15 gene-modified human natural killer cells: implications for adoptive cellular immunotherapy. Haematologica. 2004; 89:338-347.

49. Tam YK, Maki G, Miyagawa B, Hennemann B, Tonn T, Klingemann HG. Characterization of genetically altered, interleukin 2-independent natural killer cell lines suitable for adoptive cellular immunotherapy. Hum Gene Ther. 1999; 10:1359-1373. 
50. Gschweng E, De Oliveira S, Kohn DB. Hematopoietic stem cells for cancer immunotherapy. Immunological reviews. 2014; 257:237-249.

51. Koehne G, Zeller W, Stockschlaeder M, Zander AR. Phenotype of lymphocyte subsets after autologous peripheral blood stem cell transplantation. Bone Marrow Transplant. 1997; 19:149-156.

52. Badowski MS, Zhang T, Tsang TC, Harris DT. Chimeric antigen receptors for stem cell based immunotherapy. Journal of experimental therapeutics \& oncology. 2009; 8:53-63.

53. Hege KM, Cooke KS, Finer MH, Zsebo KM, Roberts MR. Systemic $\mathrm{T}$ cell-independent tumor immunity after transplantation of universal receptor-modified bone marrow into SCID mice. J Exp Med. 1996; 184:2261-2269.

54. Shiloni E, Karp SE, Custer MC, Shilyansky J, Restifo NP, Rosenberg SA, Mule JJ. Retroviral transduction of interferongamma cDNA into a nonimmunogenic murine fibrosarcoma: generation of $\mathrm{T}$ cells in draining lymph nodes capable of treating established parental metastatic tumor. Cancer immunology, immunotherapy : CII. 1993; 37:286-292.
55. Karre K, Ljunggren $\mathrm{HG}$, Piontek $\mathrm{G}$, Kiessling $\mathrm{R}$. Selective rejection of H-2-deficient lymphoma variants suggests alternative immune defence strategy. Nature. 1986; 319:675-678.

56. Piechocki MP, Ho YS, Pilon S, Wei WZ. Human ErbB-2 (Her-2) transgenic mice: a model system for testing Her-2 based vaccines. J Immunol. 2003; 171:5787-5794.

57. Yong CS, Sharkey J, Duscio B, Venville B, Wei WZ, Jones RF, Slaney CY, Mir Arnau G, Papenfuss AT, Schroder J, Darcy PK, Kershaw MH. Embryonic Lethality in Homozygous Human Her-2 Transgenic Mice Due to Disruption of the Pds5b Gene. PloS one. 2015; 10:e0136817.

58. Brouckaert G, Kalai M, Krysko DV, Saelens X, Vercammen D, Ndlovu MN, Haegeman G, D'Herde K, Vandenabeele P. Phagocytosis of necrotic cells by macrophages is phosphatidylserine dependent and does not induce inflammatory cytokine production. Molecular biology of the cell. 2004; 15:1089-1100. 